\title{
Resúmenes de Tesis: Doctorado en Ciencias Biológicas
}

\section{Caracterización morfológica y molecular del proceso de adhesión celular en plantas}

\begin{abstract}
Maria Gabriela Acosta
acosta.maria@inta.gob.ar

Director: Dr. Víctor Hugo Casco

Lugar de realización: Laboratorio de Microscopia Aplicada a Estudios Moleculares y Celulares. Facultad de Ingeniería. Universidad Nacional de Entre Ríos.

Fecha de defensa: 04 de marzo de 2016
\end{abstract}

La adhesión celular en las plantas es un hecho esencial en la comunicación célulacélula. Este proceso se ha propuesto como un paso clave en la reproducción de las Angiospermas al mediar el contacto inicial del grano de polen al estigma. La polinización es un paso crucial en el ciclo de vida de las plantas y constituye la interacción célulacélula más importante de las plantas con flores, donde el éxito de la reproducción sexual depende de múltiples interacciones entre el grano de polen y los diferentes tejidos del pistilo. Luego de dicha adhesión, se produce una comunicación cruzada entre ambas estructuras, que culmina con el rechazo (mecanismo de autoincompatibilidad o SI) o la aceptación del grano de polen propio (mecanismo de autocompatibilidad o SC). En el mecanismo SI participan proteínas que pertenecen a la superfamilia de proteínas con repeticiones armadillo (ARM). Una alta proporción de los dominios ARM en plantas se encuentran coexistiendo con dominios U-box, desempeñando funciones especializadas, la mayoría de ellas como ligasas de ubiquitina E3 (PUB-ARM). La mayor parte de las ARMs de Arabidopsis thaliana poseen dominios U-box (AtPUB-ARMs), desempeñando roles como ligasas de ubiquitina E3. En este trabajo de tesis, utilizando herramientas bioinformáticas, se encontraron 113 polipéptidos pertenecientes a esta superfamilia de proteínas en el genoma de $A$. thaliana (AtARMs). Como objetivo general del presente estudio, se propuso la caracterización del mecanismo de adhesión celular en una especie SC y asimismo, estudiar en el proceso de polinización el posible rol biológico de las proteínas AtARMs. Se caracterizó inicialmente la naturaleza química de la interacción polen-estigma, corroborando que se trata de un contacto de tipo lipoproteico. Mediante técnicas de microscopía óptica, electrónica de transmisión y de barrido, se detectaron particularidades, no descriptas previamente, de la interacción polen-estigma entre las que se destaca la discontinuidad de la traza osmiofílica del contacto y se corroboraron otras, como la reorganización de la red vacuolar en las papilas estigmáticas, con reorientación de éstas hacia el punto de contacto con el grano de polen. Por técnicas bioinformáticas, se determinó la existencia de proteínas AtARMs putativas relacionadas filogenéticamente con ARC1, una ligasa de ubiquitina E3 que participa en el mecanismo de SI en Brassica. Mediante técnicas de inmunodetección, se caracterizaron tres grupos de proteínas AtARMs los cuales mostraron perfiles diferenciales cuando se somete a las plantas a tratamiento hormo- 
nal y estrés salino. En el presente trabajo, los estudios de expresión génica utilizando RT-sqPCR mostraron que, del conjunto de transcriptos que codifican para las AtPUBARMs más relacionadas filogenéticamente con BnARC1 y que aumentaron sus niveles de expresión proteica bajo diferentes tratamientos, el polipéptido que emergió como candidato a estudiar fue AtPUB16. Esta posible ligasa de ubiquitina E3 mostró elevados niveles de expresión génica con el agregado exógeno de GA en plantas salvajes donde, por técnicas de inmunofluorescencia, se detectaron proteínas ARM en el interior de las papilas del estigma durante el contacto con el grano de polen. Asimismo, se observó por microscopia de epifluorescencia un aumento significativo de granos de polen adheridos cuando se somete a las plantas a tratamiento con GA. Para corroborar el posible rol de esta molécula, se utilizaron mutantes en el gen pub16 en los que no se verificaron incrementos de su expresión, ni en el número de granos de polen adheridos, ante el tratamiento con GA, comparada con los genotipos salvajes. En los mutantes, usando técnicas de inmunofluorescencia no se detectó la presencia de proteínas ARM en el interior de las papilas. Asimismo, mutantes en el receptor gid1a mostraron, para ambos tratamientos, un número de granos de polen adheridos similar al genotipo salvaje sin tratamiento con GA. Esto sugiere que la activación de la expresión génica de AtPUB16 sería mediada por GA. En un análisis posterior, y con el objetivo de encontrar posibles moléculas blanco para la ligasa de ubiquitina E3 AtPUB16, se observó que en flores sometidas a tratamiento con GA se verifica un aumento significativo de la expresión génica de EXO70A1, un homólogo de EXO70 de B. napus, involucrado en la acti- vidad secretora de las papilas estigmáticas, sugiriendo su posible participación en la vía de hidratación del polen propio en $A$. thaliana. Analizando tanto en A. lyrata (SI) como en $A$. thaliana la expresión génica de los transcriptos correspondientes a AtPUB8, molécula implicada en la pseudo-autocompatibilidad (PSC) en especies SI, se observaron aumentos significativos en la expresión de dichos transcriptos, en presencia de GA en genotipos salvajes de A. thaliana. Su aumento en una especie SC, podría sugerir su participación en vías que refuerzan la SC en A. thaliana. Los hallazgos presentados en esta tesis doctoral, permiten comenzar a dilucidar el rol clave de las proteínas ARM en el mecanismo de polinización de $A$. thaliana y asimismo, la sensibilidad diferencial que este conjunto de moléculas tienen frente a diferentes condiciones de tratamiento. En particular, se determinó que AtPUB16 actuaría como una ligasa de ubiquitina $\mathrm{E} 3$, clave en la promoción de los contactos polenestigma en flores de $A$. thaliana sometidas a tratamiento con GA, potenciando los mecanismos de autopolinización.

\section{Morphological and molecular character- ization of cell adhesion process in plants}

Cell adhesion in plants has been proposed as a key step in the reproduction of the Angiosperms by mediating the initial contact pollen-stigma and involve proteins belonging to the protein superfamily with armadillo repeats (ARM). In Arabidopsis thaliana AtPUB-ARMs play roles as E3 ubiquitin ligases. In this thesis, using bioinformatic tools, we found 113 polypeptides belonging to this superfamily of proteins in of $A$. thaliana. In order to characterize the cellular adhesion mechanism and to study the possible biological role of the AtARMs pro- 
teins, initially the lipoprotein chemical nature of the pollen stigma interaction was corroborated by the microscopic techniques. Putative AtARMs phylogenetically related with BnARC1, an E3 ubiquitin ligase, were determined and by immunodetection techniques AtARMs proteins with differential profiles were characterized when the plants were submitted to hormonal treatment and saline stress. Gene expression studies showed that, from the set of transcripts coding for the most phylogenetically related AtPUB-ARMs with BnARC1, increasing their levels of protein expression under different treatments. Only AtPUB16 showed high levels of gene expression with the exogenous aggregation of GA in WT plants where by immunofluorescence techniques AtARMs proteins were detected inside the stigma papillae during pollen-stigma contact. In pub16 mutants no increase in expression was observed, when compared to GA-treatment, and immunofluorescence techniques not detect the AtARMs proteins inside the papillae. It was determined that AtPUB16 would act as an ubiquitin E3 ligase, key in the promotion of pollen-stigma contacts in $A$. thaliana flowers undergoing treatment with GA, enhancing the self-pollinating mechanisms.

\section{Propágulos del zooplancton: importancia en el mantenimiento de la diversidad en los ambientes acuáticos y dispersión de las especies}

\section{Yamila Soledad Battauz}

yamilabattauz@gmail.com

Directora: Dra. Susana Beatriz José de Paggi Co-Director: Dr. Juan Cesar Paggi

Lugar de realización: Instituto Nacional de Limnología (CONICET- UNL). Laboratorio de Plancton. Facultad de Bioquímica y Ciencias Biológicas. Universidad Nacional del Litoral Fecha de defensa: 8 de marzo de 2016

El presente trabajo aborda la influencia de la emergencia de los estadios de resistencia en la diversidad del zooplancton en ambientes acuáticos de la llanura de inundación del río Paraná Medio y los vectores que contribuyen a su dispersión en la región. Se comparó la diversidad del zooplancton de la columna de agua en una laguna de la llanura de inundación, con la diversidad del banco de estadios de resistencia en sedimentos costeros expuestos. Se diseñó una trampa de emergencia adaptada a las condiciones de los ambientes estudiados, que se utilizó para analizar la emergencia de estadios de resistencia in situ en sedimentos de fondo en relación con la composición de rotíferos, cladóceros y copépodos de la columna de agua, en una laguna. Para el estudio de los potenciales vectores de dispersión, se determinó la existencia de estadios de resistencia en el aparato radicular y porciones sumergidas de tallos en las macrófitas flotantes comunes en la región como Azolla filiculoides, Eichhornia crassipes, Eichhornia azurea, Pistia stratiotes, Limnobium spongia, Nymphoides indica y de su viabilidad de eclosión. También se determinó la existencia de estadios de resistencia de zooplanctontes en el tracto digestivo del pez Prochilodus linneatus y su viabilidad de eclosión. 
Los resultados mostraron que los sedimentos costeros constituyen una importante fuente potencial de formas de resistencia disponibles para ser reclutadas por la masa de agua y también para ser dispersadas. La trampa de emergencia resultó efectiva para el estudio de eclosiones de las poblaciones naturales del ensamble zooplanctónico en el área de mayor profundidad de la laguna. En ambas experiencia de eclosión (ex situ e in situ) los rotíferos fueron los más diversos y abundantes, registrándose los géneros Anuraeopsis, Colurella, Lecane, Lepadella, Mytilina, Scaridium, Testudinella. Se registraron patrones en la dinámica de eclosión de las especies tanto en las experiencias en laboratorio como a campo. Los resultados experimentales mostraron que un número importante de especies, en su mayoría rotíferos pueden ser dispersados por los vectores estudiados.

Propagules zooplankton: Importance in maintaining diversity in aquatic environments and dispersal of species

This study, addresses the influence of the emergence of resting stages in the diversity of zooplankton in aquatic environments of the Middle Paraná River floodplain and the vectors that contribute their dispersion in the region. The diversity of zooplankton present in the water column of the lake in the floodplain was compared, with the diversity of the resting stages banks in exposed littoral sediments. Emergency trap was desig- ned, adapted to the conditions of the studied environments, which was used to comparatively analyze the composition of rotifers, cladocerans and copepods present in a lake and the emergence of resting stages in situ, in bottom sediments. For the study of the potential vectors of dispersal, it was determined the existence of resting stages in the root system and submerged portions of stems in free-floating macrophytes more common in the region as Azolla filiculoides, Eichhornia crassipes, Eichhornia azurea, Pistia stratiotes, Limnobium spongia, Nymphoides indica and hatching viability. Also, it was determined the existence of resting stages of zooplankton in the digestive tract of the fish Prochilodus linneatus and hatching viability.

The results showed that littoral sediments are an important potential source of forms of resistance available to be recruited by the mass of water and also to be dispersed. The emergency traps are effective for the study of natural hatching of assemblage zooplankton in the area of greatest depth of the lake. In both experience the hatching (ex situ and in situ) rotifers were the most diverse and abundant, genera Anuraeopsis, Colurella, Lecane, Lepadella, Mytilina, Scaridium, Testudinella. Patterns in the dynamics of both species hatch on experience in laboratory and field were recorded. Experimental results showed that a significant number of species, mostly rotifers can be dispersed by the vectors studied 


\section{Estudios funcionales de proteínas mitocondriales de Arabidopsis relacionadas con los mecanismos de defensa generados por estrés biótico y abiótico}

\section{Francisco Colombatti}

fran.colombatti@gmail.com

Director: Dra. Elina Welchen

Co-Director: Dr. Daniel González

Lugar de realización: Laboratorio de Biología Molecular. Instituto de Agrobiotecnología del Litoral (UNL-CONICET)

Fecha de defensa: 22 de agosto de 2016

Los genes de la familia OXR (del inglés Oxidation Resistance) fueron descubiertos en una búsqueda de genes capaces de revertir el fenotipo de estrés oxidativo en levaduras. Desde los primeros hallazgos en el año 2000, se han reportado múltiples estudios en distintos organismos tales como ratones, Drosophila melanogaster, mosquitos y humanos. En levaduras existe un único gen representante de la familia, mientras que en mamíferos se han reportado 5 genes que pueden transcribirse a su vez en distintas variantes de splicing. En levaduras se demostró una localización mitocondrial y una fuerte inducción frente a estrés oxidativo para la proteína ScOXR1. En mamíferos se han demostrado localizaciones en mitocondria, citosol y núcleo para HsOXR1 y NCOA7, así como también expresión diferencial en distintos tejidos. En Drosophila, el primer miembro identificado de la familia OXR se nombró L82, al que se le atribuyó un rol central en el desarroIlo. En otro modelo de insecto, en el mosquito Anopheles gambiae, se demostró un vínculo estrecho entre la expresión de OXR1 y la tolerancia al estrés biótico. En todos los casos se demostró que estas proteínas ejercen su rol mediante alteraciones en la respuesta al estrés oxidativo. Sin embargo, nada se sabe sobre la función que estos genes podrían estar desarrollando en el reino vegetal. Por este motivo, en este trabajo de Tesis nos propusimos estudiar la familia OXR en Arabidopsis thaliana.

Esta familia está constituida por 5 miembros, los cuales denominamos AtOXR1, AtOXR2, AtOXR4, AtOXR5 y At5g06260. Comenzamos con el estudio de los genes AtOXR2 y AtOXR4 ya que presentaron mayor identidad de secuencia con los previamente estudiados HsOXR1 y ScOxr1. Utilizando un sistema de bacterias mutantes incapaces de evitar o reparar el daño en el ADN, observamos que las proteínas AtOXR2 y AtOXR4 tienen un efecto de protección contra el daño oxidativo en esta cepa de bacterias. Además, cuando se complementaron levaduras mutantes en el gen Scoxr1 observamos una reversión en el fenotipo de sensibilidad al estrés oxidativo. Estos resultados sugieren que las proteínas AtOXR2 y AtOXR4 podrían cumplir un rol en la reparación del $A D N$ o en su protección contra el daño oxidativo, tal como se ha sugerido previamente para sus homólogos en levaduras y humanos. Los resultados obtenidos en bacterias y levaduras sugieren que AtOXR2 y AtOXR4 podrían tener un rol similar en plantas y participar en la respuesta al estrés oxidativo. 
Los estudios de localización subcelular en plantas transformantes estables de Arabidopsis demostraron que AtOXR2 y AtOXR4 se localizan en mitocondrias de células de raíz, en plantas crecidas en condiciones normales. Además, las proteínas quiméricas AtOXR24 y AtOXR42, desarrolladas en este trabajo de Tesis, también comparten esa localización subcelular.

Por otro lado, el estudio de las regiones promotoras de los genes codificantes para AtOXR2 y AtOXR4 reveló un perfil de expresión similar. Ambos promotores dirigen la expresión en plantas recién germinadas principalmente en meristemas; posteriormente en cotiledones, luego en el primer par de hojas, y conforme pasa el tiempo la expresión disminuye. Cuando la planta florece, ambos promotores dirigen la expresión de GUS, la cual se incrementa hasta llegar a polen maduro. La expresión de AtOXR2 y de AtOXR4 se incrementa ante distintas condiciones de estrés, tanto cuando la expresión se evaluó mediante actividad del gen reportero GUS como mediante Northen Blot o RT-qPCR. Para el caso de AtOXR2 observamos un aumento de la expresión, tanto del transcripto como del gen reportero, en condiciones que producen ROS como luz prolongada, calor, UV-B y 3-AT. Para el gen AtOXR4 observamos un incremento en los niveles de expresión tanto en el gen reportero como en los niveles de transcripto en presencia de SA. Los resultados de expresión así como de inducción diferencial para ambos genes, enfatizan en una posible especialización en la función para las proteínas AtOXR2 y AtOXR4.

Las plantas que sobreexpresan AtOXR2 (35S::AtOXR2) tienen una estructura radicular más compleja, mientras que plantas deficientes en dicho gen mostraron el fenotipo opuesto. En condiciones de estrés severo, las plantas 35S::AtOXR2 desarrollan una raíz principal de mayor longitud. Las plantas que sobreexpresan AtOXR2 llegan a tener 3 veces más biomasa que sus pares salvajes. Mediante la caracterización fenotípica detectamos que estas plantas presentan diferencias de tiempo en el pasaje al estadio reproductivo, las cuales podrían explicar las diferencias en el desarrollo foliar. Así, estas plantas tienen mayor tiempo para invertir la energía capturada en el desarrollo foliar; mientras que una vez que realizaron el cambio metabólico a la etapa reproductiva, cuentan con una maquinaria capaz de captar más cantidad de energía lumínica. Parte del incremento en la lámina foliar se debe a un aumento en el tamaño celular, mientras que el resto se corresponde con un aumento en el número de células. Este último proceso, podría ser la consecuencia de iniciar el arresto celular a tiempos posteriores. En la misma dirección, encontramos que el patrón de áreas foliares es similar en plantas 35S::AtOXR2 y en plantas salvajes. Además, es probable que tengan una pared celular menos rígida, lo cual les permitiría a estas plantas crecer más.

Los parámetros de fluorescencia de la clorofila indican que las plantas 35S::AtOXR2 son más eficientes en el uso de luz capturada. Esta característica se ve acompañada de una tasa de transporte de electrones incrementada, posiblemente por una capacidad de restauración del estado redox aumentada. En coincidencia, los resultados de intercambio gaseoso de plantas 35S::AtOXR2 demuestran que estas plantas son capaces de fijar más $\mathrm{CO} 2$ que sus pares salvajes. Todas estas características, mayor fijación de $\mathrm{CO} 2$, mayor tasa de transferencia de electrones y mayor 
lámina foliar, dan como resultado un organismo con mayor aptitud y eficiencia a la hora de convertir la luz en energía química. Así, estas plantas son capaces de producir mayor cantidad de semillas.

Las plantas que sobreexpresan AtOXR2 retienen el agua con mayor avidez, mientras que las plantas $\delta 0 x r 2$ muestran el comportamiento contrario. Estas diferencias serían consecuencia de un cierre estomático acelerado en plantas 35S::AtOXR2. Plantas 35S::AtOXR2 de 6 semanas tienen alterado su contenido de ABA, posiblemente de forma dependiente de los niveles de AtOXR2. Por otro lado, las semillas 35S::AtOXR2 demostraron germinar y establecerse bajo condiciones de estrés osmótico y concentraciones de ABA que inhiben el crecimiento en plantas WT.

El análisis del transcriptoma de plantas que sobreexpresan AtOXR2 nos permitió determinar que tienen un perfil transcripcional basal similar al de plantas de Arabidopsis que están siendo sometidas a situaciones de estrés. Además, demostramos que las plantas 35S::AtOXR2 tienen mayor concentración de ROS basales, mayores niveles de peroxidación lipídica, así como mayores niveles de las moléculas antioxidantes ascorbato y glutatión total. En línea con las observaciones de fluorescencia de la clorofila, las plantas 35S::AtOXR2 demostraron ser tolerantes al estrés por alta intensidad lumínica.

De acuerdo con nuestros resultados, es probable que estas plantas estén mejor preparadas para enfrentar el estrés biótico. Estas plantas tienen mayor concentración de la fitohormona SA respecto de plantas salvajes. Frente a la infección con P. syringae, las plantas 35S::AtOXR2 son capaces de montar una respuesta de defensa con mayor velocidad que las plantas salvajes, pudiendo eliminar al patógeno en menor tiempo.

Los resultados obtenidos en esta tesis aportan información novedosa sobre la función de proteínas de la familia OXR en plantas y sientan las bases para futuras investigaciones. Debido a la mejora en las propiedades de interés agronómico que presentan las plantas que sobreexpresan AtOXR2, es posible pensar en el uso de este gen como una herramienta novedosa y útil para el desarrollo de nuevas tecnologías.

\section{Functional studies of arabidopsis mito- chondiral proteins related to defense mech- anisms against biotic and abiotic stress}

OXR (Oxidation Resistance) family genes were discovered during a search of genes capable of revert oxidative stress phenotype

From its discovery to date multiple studies in yeast, humans and mosquitoes have been published. Yeast genome contains only one gene representing the family, while in mammalian previous studies reported 5 members that are able to be spliced into different isoforms. In yeast, ScOXR1 gene is located in mitochondria and is strongly induced by oxidative stress. While in mammals previous studies reported mitochondrial, cytosolic and nuclear localization for HsOXR1 and NOCA7, as well as differential expression on different tissues. A role in development was previously described for $L 82$, the first Drosophila melanogaster reported OXR gene. In another insect model, Anopheles gambiae, it was shown a link between OXR1 expression and biotic stress tolerance. Altogether, these studies, showed correlation between OXR genes expression and oxidative stress response modification. However, nothing is known about the function of this family gene could be carrying out on the plant kingdom. For this 
reason, in this Thesis work we focused on Arabidopsis thaliana OXR protein family.

Arabidopsis OXR family is composed by 5 members, which we named AtOXR1, AtOXR2, AtOXR4, AtOXR5 and At5g06260. We started our work studying AtOXR2 and AtOXR4, whose sequence identity was the highest, when compared it to HsOXR1 and ScOXR1. By means of a mutant bacterial system, we showed that AtOXR2 and AtOXR4 are able to exert a protective effect on such sensitive bacteria, by protecting or repairing the damage of DNA exerted by oxidative stress growing conditions. Moreover, when ScOXR1 mutant yeast were complemented with a yeast mitochondrial-targeted version of AtOXR2 and AtOXR4, we found a reversion on the oxidative stress sensitivity phenotype. These results suggests that AtOXR2 and AtOXR4 may play a role in preventing or repairing DNA against oxidative stress, as previously been reported for its yeast and mammalian homologues. Furthermore, these results suggest that AtOXR2 and AtOXR4 may have a role in oxidative stress response in plants.

We demonstrated that AtOXR2 and AtOXR4 are localized in mitochondria of root cells, when plants were grown on normal conditions. Furthermore, chimeric proteins AtOXR24 and AtOXR42 developed in this Thesis work, are localized on mitochondria of root cells too on stable Arabidopsis transgenic plants. Moreover, studies on expression patterns conferred by promoter regions of both genes revealed a similar expression profile. Both promoters direct expression on newly germinated plants mainly in meristems; later on cotyledons, and then in the first couple of leaves, and as time goes on reporter gene expression disappears. When the plant blooms, both promoters drive the expression of report- er gene GUS, which increases as time goes on until pollen reaches mature stage.

In this work, we showed that expression of AtOXR2 and AtOXR4 is increased under different stress conditions, measured by GUS activity of both promoters as well as by Northern Blot or RT-qPCR. When we studied AtOXR2 we detected induction of both transcripts and reporter gene, under conditions that stimulate ROS production such as lengthened photoperiod, heat, UV-B and 3-AT. When we studied AtOXR4, an increase of the expression levels of transcript as well as reporter gene was detected under presence of salicylic acid (SA). Results of expression patterns and differential induction upon different stimulus, emphasizes our hypothesis of gene specialization and distinctive roles for AtOXR2 and AtOXR4.

Plants overexpressing AtOXR2 (35S::AtOXR2) show a more complex root structure, while we detected that Arabidopsis plants deficient in AtOXR2 ( $\triangle$ oxr2) exhibit the opposite phenotype. Under severe stress conditions, 35S::AtOXR2 plants are able to develop a main root larger than WT roots. When plants overexpressing AtOXR2 grow up they reach three fold more biomass than WT plants. By means of phenotypic characterization we detected that these plants switch to reproductive stage later than WT plants. This would allow 35S::AtOXR2 plants convert more light energy into leaves; while once they switched to reproductive stage, they developed a machinery capable of capture more light. A portion of the increase in leaf size is due to a slight increase in cell size, while a major cause of leaf size is due to an increase in cell quantity. This could be consequences of starting cellular arrest to later times. In the same direction, we found that pattern 
of leaf size is similar in plants overexpressing AtOXR2 and WT plants. Additionally, 35S::AtOXR2 plants may have a less rigid cell wall which would allow these plants to grow up with less constraint.

By measuring chlorophyll fluorescence parameters, we detected that 35S::AtOXR2 plants are more efficient in the use of captured light. This characteristic is accompanied with an increased electron transport chain, possibly by an improved redox state restoration. Gas exchange experiments showed that 35S::AtOXR2 plants are able to fix more $\mathrm{CO} 2$ than WT plants. Altogether, these characteristics, increased $\mathrm{CO} 2$ fixation, improved electron transport chain and increased leaf size, give rise to an organism with major aptitude to convert light into chemical energy. Thus, these plants are capable to produce more seeds.

Plants overexpressing AtOXR2 hold water stronger than WT plants, while $\triangle$ oxr2 plants shows the opposite behavior. These differences could be due to an accelerated stomata closure in 35S::AtOXR2 plants. When these plants reach six weeks of age, they have altered $A B A$ content, possibly in an AtOXR2 dependent-dose manner. Moreover, 35S::AtOXR2 seeds showed different germination and establishment rates under osmotic stress conditions and under ABA concentrations that inhibits growing of WT plants.

Transcriptional analysis of plants overexpressing AtOXR2 allowed us to determine that these plants possess a transcriptional profile similar to Arabidopsis plants exposed to stress conditions. Moreover, we showed that 35S::AtOXR2 plants have increased ROS concentration, increased lipid peroxidation levels, as well as increased scavengers molecules Ascorbate and Gluthation. Likely, these plants are better prepared to face biotic stress.

In accordance with chlorophyll fluorescence determinations, 35S::AtOXR2 plants showed more tolerance to high light stress. Moreover, these plants have more SA concentration than WT plants. When 35S::AtOXR2 plants were challenged with $P$. syringe, these plants are capable to mount a faster response tan WT plants, producing pathogen elimination in less time.

Results obtained in this Thesis work bring newly information about the functions of proteins from OXR family on plants, providing new clues to understand the role of these proteins and establishing a basis for future studies. Due to improving in properties of agronomic interest that present plants overexpressing AtOXR2, is possible to think about using this gen as a new tool useful to develop new technologies.

\section{Ecoepidemiología de Rickettsia parkeri en el Delta del Paraná}

\section{Valeria Carolina Colombo}

valecc1983@yahoo.com.ar

Director: Dr. Pablo Martín Beldomenico

Co-Director: Dr. Santiago Nava

Lugar de realización: Instituto de Ciencias
Veterinarias del Litoral (UNL-CONICET), Laboratorio de Ecología de Enfermedades. Facultad de Ciencias Veterinarias. Universidad Nacional del Litoral

Fecha de defensa: 28 de marzo de 2016 
Rickettsia parkeri forma parte de los patógenos que integran el grupo de las fiebres manchadas transmitidas principalmente por garrapatas del "Grupo de Amblyomma maculatum". En Argentina se detectaron casos humanos en las provincias de Córdoba y la Rioja transmitidos por Amblyomma tigrinum, y en Chaco, Entre Ríos y Buenos Aires por Amblyomma triste, jugando esta especie de garrapata un rol fundamental en la ecoepidemiología de este patógeno en la región. Poco se sabe tanto de la ecología de $R$. parkeri como de A. triste, a pesar de que conocer los aspectos ecológicos de ambos es fundamental a la hora de comprender la dinámica de la fiebre manchada producida por $R$. parkeri y así poder evaluar situaciones de riesgo para la salud pública. En la eco-región Delta e Islas del Paraná, los estadios inmaduros de $A$. triste se encuentran parasitando principalmente roedores sigmodontinos, mientras que los estadios adultos se encuentran en mamíferos silvestres de mayor tamaño así como en animales domésticos y humanos. En la presente tesis se estudió la fauna de los ectoparásitos de roedores sigmodontinos del Delta del Paraná, con énfasis en garrapatas. Por otro lado, se evaluó qué factores influyen en el parasitismo de los estadios inmaduros de $A$. triste en sus hospedadores sigmodontinos así como el rol de estos en la ecoepidemiología de $R$. parkeri.

Como resultados principales pueden mencionarse el hallazgo de diversas familias y especies de garrapatas, ácaros, pulgas y piojos que parasitan a los roedores silvestres del área de estudio, reportando primeros registros para las asociaciones A. triste - Holochilus brasiliensis e Ixodes loricatus $-H$. brasiliensis. Entre los factores ambientales estudiados se encontró que los estadios inmaduros de $A$. triste tienen una distribución estacional a lo largo del año con abundancias más elevadas en verano, y que esta distribución dependió de las condiciones ambientales dadas por la cantidad de precipitaciones, valores de temperatura mínima y déficit de saturación. La presencia de ganado fue otro de los factores que se asociaron positivamente a la abundancia de $A$. triste en roedores sigmodontinos; dependiendo la magnitud de esta asociación de la densidad de roedores en el caso de las larvas, así como también se encontraron mayores abundancias de larvas de $A$. triste en roedores en ambientes de bosques implantados ante la co-infestación con I. loricatus. Otro de los factores significativos hallados en el presente trabajo fue la co-infestación con otros ectoparásitos, tanto larvas como ninfas de $A$. triste se correlacionaron positivamente con la co-infestación con I. loricatus, siendo esta la interacción más relevante encontrada en el presente trabajo. También fueron significativas las asociaciones entre larvas de $A$. triste y pulgas y piojos. Factores intrínsecos al hospedador como la especie, sexo, condición corporal, largo del cuerpo y títulos de anticuerpos naturales también se encontraron asociados en diferente medida a la abundancia de $A$. triste, siendo uno de los hallazgos más importantes en este aspecto la gran abundancia media de A. triste detectada en Oxymycterus rufus, convirtiéndolo en un hospedador muy relevante para el vector de $R$. parkeri.

En cuanto a la detección de $R$. parkeri a partir de tejidos de roedores sigmodontinos, si bien no pudo ser aislado ADN de $R$. parkeri a partir de las muestras analizadas, se detectaron individuos seropositivos a esta bacteria, siendo nuevamente $O$. rufus 
la especie que presentó los valores más elevados de seroprevalencia. También se encontró que aquellos roedores que tuvieron las mayores cargas de A. triste tuvieron una mayor probabilidad de ser seropositivos a $R$. parkeri.

El presente estudio permitió conocer cuáles son los factores ambientales, del hospedador y el efecto de la co-infestación con otros ectoparásitos que están asociados y podrían influir en la abundancia media de los estadios inmaduros de $A$. triste en los roedores sigmodontinos estudiados. También permitió conocer que la especie de roedor que actúa como principal hospedador de $A$. triste en el área de estudio es $O$. rufus, siendo además la especie que presentó los niveles más elevados de seroprevalencia de $R$. parkeri, pudiendo entonces cumplir un rol principal en la dinámica y distribución de este patógeno en el Delta del Paraná.

El hecho de conocer qué factores están implicados en las mayores abundancias de $A$. triste nos permite predecir qué zonas pueden ser más o menos propensas a la presencia de A. triste. Cabe destacar la importancia de considerar el efecto positivo que genera la presencia de ganado bovino sobre la abundancia de $A$. triste a la hora de planificar el asentamiento de explotaciones ganaderas en regiones donde está presente $R$. parkeri. Futuros estudios experimentales que evalúen la potencialidad de $O$. rufus como amplificador de R. parkeri y los mecanismos por los cuales representa un importante hospedador de A. triste, permitirán dilucidar aquellos aspectos de la interacción A. triste - O. rufus - R. parkeri que no han podido ser comprendidos mediante el presente estudio observacional.

\section{Ecoepidemiology of Rickettsia parkeri in the Paraná Delta}

In the present thesis, the ectoparasites of sigmodontine rodents of the Paraná Delta, their role in the ecoepidemiology of Rickettsia parkeri and the variables that could be associated with the abundance of its vector, Amblyomma triste immature stages, had been studied.

Different ticks, mites, lice and fleas where found parasitizing the wild rodents studied, while the associations $A$. triste - Holochilus brasiliensis and Ixodes loricatus $-\mathrm{H}$. brasiliensis were not registered before. Season had a strong influence for immature $A$. triste with the greatest records in summer. $A$. triste larvae burdens were also associated with levels of precipitations, minimum temperatures and saturation deficit. The presence of cattle was positive associated with A. triste burdens in rodents. Co-infestation with other ectoparasites was another relevant variable in the ecology of $A$. triste; larvae and nymphs of $A$. triste were associated with burdens of $I$. loricatus, lice and fleas. Concerning host factors, host species, sex, body condition, body length and natural antibodies were correlated in different ways with $A$. triste, being one of the most relevant findings the association between $A$. triste burdens and rodent species, in which Oxymycterus rufus had the greatest burdens.

On the other hand, $R$. parkeri DNA was not successfully amplified from rodent tissues, but many individuals were found seropositive to $R$. parkeri, being again $O$. rufus the species with the greatest seroprevalence. The knowledge of the factors that are associated with higher burdens of $A$. triste in their rodent hosts let us predict which areas are more or less prone to the development of $A$. triste. 


\section{Desarrollo de una plataforma tecnológica innovadora para producción de vacunas virales recombinantes. Su aplicación al virus de la rabia}

\section{Diego Fontana}

dfontana@fbcb.unl.edu.ar

Director: Dr. Claudio Prieto

Co-Directora: Dra. Marina Etcheverrigaray

Lugar de realización: Laboratorio de Cultivos Celulares. Facultad de Bioquímica y Ciencias Biológicas. Universidad Nacional del Litoral

Fecha de defensa: 22 de marzo de 2016

La rabia es una zoonosis viral aguda, con una mortalidad cercana al $100 \%$ y cuyo único tratamiento disponible en la actualidad es la vacunación. El modo más común de contagio al ser humano es el contacto con saliva de animales infectados, principalmente perros. Por esta razón, la vacunación de animales de compañía es obligatoria en la Argentina, buscando de esta forma controlar la circulación viral y disminuir el riesgo de contagio.

Las vacunas antirrábicas hoy disponibles en el mercado, tanto humanas como veterinarias, son basadas en virus inactivado producido en cultivos celulares. Aunque eficaces, estas vacunas poseen efectos adversos importantes y, además, para su producción es necesaria la manipulación del virus de la rabia activo, haciendo que en el proceso se necesiten instalaciones con elevada contención viral. Debido a esto, surge la necesidad de diseñar una vacuna antirrábica de nueva generación, que sea eficaz y totalmente biosegura.

Las virus-like particles (VLPS) son excelentes candidatos vacunales ya que son capaces de generar una potente y equilibrada respuesta inmune $y$, al ser partículas que no contienen genoma viral, son bioseguras. Nuestra hipótesis consistió, entonces, en desarrollar VLPs para rabia (RV-VLPS) expresando en células de mamífero proteínas estructurales del virus. Por un lado, se evaluó la expresión de la gliproteína G y, por otro, la co-expresión de la glicoproteína $\mathrm{G}$ y la proteína de matriz o M.

En una primera etapa de trabajo, se evaluó la expresión de RV-VLPs en tres líneas celulares distintas: HEK293, BHK-21 y VERO. La expresión de la glicoproteína G fue confirmada por citometría de flujo, microscopía de fluorescencia y ELISA, mientras que la expresón de la proteína $M$ fue estudiada por RT-PCR. De los resultados obtenidos, se seleccionaron las líneas recombinantes HEK293 para continuar el trabajo.

Posteriormente, se llevó a cabo la caracterización de las RV-VLPs obtenidas. Se observaron partículas circulares, con envoltura y con un diámetro hidrodinámico promedio de $60 \pm 20 \mathrm{~nm}$. A su vez, realizando ensayos de microscopía electrónica asociada a inmunomarcación con oro coloidal, se confirmó que la glicoproteína G estaba anclada en la membrana y expuesta sobre la superficie de las VLPS. De todas las características estudidadas, no se encontraron diferencias morfológicas entre las RV-VLPS producidas por las líneas celulares recombinantes que expresan solo la glicoproteína G y por las que expresan ambas proteínas. Por otro lado, tampoco se logró obtener una 
mayor productividad de RV-VLPs cuando la proteína $\mathrm{M}$ fue co-expreada. A partir de estos resultados, entonces, se decidió continuar el trabajo con la línea celular HEK293 que expresa solo la glicoproteína G.

Más adelante, y con el objetivo de evaluar la inmunogenicidad de las RV-VLPs producidas, se llevó a cabo un protocolo de inmunización en ratones. De estos experimentos se pudo concluir que las RV-VLPs son capaces de inducir la producción de anticuerpos específicos, y que los títulos obtenidos fueron comparables a los inducidos por vacunas comerciales, tanto veterinaria como de uso humano. Además, se confirmó que los anticuerpos producidos poseen capacidad neutralizante, característica fundamental para una vacuna antirrábica. Por otro lado, para confirmar si la respuesta inmune inducida es capaz de proteger a individuos vacunados, se llevó a cabo el test de potencia del NIH para vacuna antirrábica. De los resultados de este ensayo se pudo concluir que las RV-VLPS son protectivas y que la potencia de vacuna antirrábica obtenida fue superior al mínimo requerido para una vacuna veterinaria.

A partir de esos resultados, se seleccionó un clon celular productor, para ser utilizado en la producción de la vacuna. Fue seleccionado el clon adhP2E5, el cual fue analizado confirmando su productividad y su estabilidad de expresión en el tiempo. Posteriormente, dicho clon fue adaptado para su crecimiento en suspensión en medio libre de suero, obteniendo así un cultivo que es capaz de llegar a altas densidades celulares sin la formación de agregados. El mismo fue renombrado como SP2E5. Se estudiaron las características de las RV-VLPs producidas por el mismo, demostrando que sus propiedades no se vieron modificadas por el cambio en las condiciones de cultivo.

Finalmente, el clon sP2E5 fue cultivado en reactores de 1 y $5 \mathrm{~L}$, operados en modo continuo. Los resultados de dichas fermentaciones brindaron información acerca de la escalabilidad del proceso, confirmando que las RV-VLPs son producidas durante todas las etapas de cultivo, el cual puede mantenerse por tiempos prolongados, demostrando de esta forma la elevada productividad del proceso.

En conclusión, todos los resultados obtenidos durante este trabajo de tesis confirmaron que el proceso desarrollado constituye una plataforma de producción de una vacuna antirrábica de última generación, totalmente biosegura.

\section{Development of an innovative platform} for the production of viral recombinant vaccines. Its application to the rabies virus

The main goal of this thesis was to develop a new generation vaccine for rabies, based on the expression of virus-like particles (RV-VLPS) in mammalian cells. In a first stage of work, the expression of RV VLPs in three different cell lines, HEK293, VERO and BHK-21, was evaluated. The glycoprotein $G$ expression was confirmed by flow cytometry, fluorescence microscopy and ELISA. From the results obtained, the recombinant HEK293 line was selected for further work. Subsequently, it was performed the morphological and physicochemical characterization of the RV-VLPS obtained and, later, we performed an immunization protocol in mice, where it was concluded that the RV-VLPS are capable of inducing the production of neutralizing antibodies. On the other hand, it was carried out the NIH potency test for rabies vaccine 
confirming that the RV-VLPs induce a protective immune response.

From these results, a producer cell clone which was adapted for growth in suspension with serum free medium was selected. Finally, the clone sP2E5 was cultured in 1 and $5 \mathrm{~L}$ bioreactors, operated in continuous mode, confirming that RV-VLPs are pro- duced during all stages of culture, which can be maintained for long periods, thus demonstrating the high productivity of process.

In conclusion, the results obtained during this thesis confirmed that the process developed is a platform for production of a new generation rabies vaccine, totally biosecure.

\section{Propiedades fisicoquímicas de Metaloproteínas, Sistemas Modelo y Ligandos de iones metálicos relevantes en Biología}

\section{Vanina Gisela Franco \\ vgfrancom@fbcb.unl.edu.ar \\ Director: Dr. Carlos Dante Brondino \\ Co-Director: Dr. Alberto Claudio Rizzi \\ Lugar de realización: Departamento de Física. Facultad de Bioquímica y Ciencias Biológicas. Universidad Nacional del Litoral Fecha de defensa: 6 de octubre de 2016}

El estudio de sistemas biológicos se puede realizar a partir de dos enfoques opuestos y complementarios: el análisis del sistema completo o la evaluación de sus componentes aislados. Éste último permite explicar los fenómenos que ocurren cuando las unidades que forman parte del mismo interactúan. En el presente trabajo de tesis se han utilizado espectroscopia de resonancia paramagnética electrónica y espectroscopia de rotación para el estudio de enzimas involucradas en el ciclo del azufre y obtenidas de la bacteria sulfato-reductora Desulfovibrio desulfuricans desde los dos enfoques mencionados anteriormente. En la reducción de sulfato a sulfito, intervienen ATP sulfurilasa y APS reductasa presentando ambas metaloenzimas centros paramagnéticos en su estruc- tura. Mediante la técnica de resonancia paramagnética electrónica en fase condensada, se caracterizaron estructural y magnéticamente estas dos metaloproteínas y el sistema modelo de cobre [Cu(glu)phen]. siendo glu = ácido L-glutámico y phen = 1,10-fenantrolina Se determinaron el rol del metal en la estructura y las propiedades magnéticas de ATP sulfurilasa; las interacciones de los sitios paramagnéticos durante el proceso de transferencia electrónica en APS reductasa y los caminos químicos e interacciones magnéticas de sitios metálicos en presencia de los ligandos orgánicos, glu y phen en el complejo de cobre [Cu(glu)phen]. En fase gas se caracterizaron dos ligandos de interés biológico: ácido picolínico y nicotinamida, mediante espectroscopia de rotación siendo las muestras sólidas previamente ablacionadas e inyectadas en un jet supersónico. Ambas moléculas presentan un anillo piridínico lo que ofrece posibilidades conformacionales para la formación de complejos con metales de transición y posibilita interacciones puente hidrógeno e hidrofóbicas, típicas de las que aparecen en metaloproteínas. De cada uno de los ligandos, se determinaron los confór- 
meros teóricos y experimentales y se caracterizaron mediante parámetros propios de la espectroscopia rotacional. Se compararon las estructuras cristalinas de los ligandos (fase condensada) con sus confórmeros en fase gas, lo que permitió el análisis de la configuración más estable para generar caminos químicos entre centros metálicos presentes en metaloproteínas.

Physicochemical Properties of Metalloproteins, Model Systems and Metal Ion Ligands Relevant in Biology

In this thesis we have used electron paramagnetic resonance spectroscopy and rotation spectroscopy for the study from these two approaches in enzymes involved in the sulfur cycle, obtained from the sulfate-reducing bacteria Desulfovibrio desulfuricans. In the reduction of sulfate to sulfide, the metalloenzymes ATP sulfurylase and APS reductase are involved, both have paramagnetic centers. By the technique of electron paramagnetic resonance in condensed phase, these two structurally and magnetically metalloproteins and a copper model system were characterized. The role of the metal in the structure and the mag- netic properties of ATP sulfurylase, interactions of paramagnetic sites in the electron transfer process in APS reductase and the chemical pathways and interactions between magnetic metal sites in the presence of the organic ligands, L-glutamic acid and 1,10-phenantroline in the copper complex [Cu(glu)phen] were determined. In gas phase two ligands of biological relevance (picolinic acid and nicotinamide) are characterized. The solid molecules being previously ablated and injected into a supersonic jet. Boths molecules have a piridinic ring, which provides conformational possibilities for the formation of transition metal complexes analogous presenting hidrogen bonds and hidrofobic interactions to active sites of proteins. For each ligand, the theoretical and experimental conformers were determined and characterized by spectroscopic parameters specific to it the rotational spectroscopy. The crystal structures of the ligands in condensed phase were compared to the conformers in gas phase, allowed the analysis of the more stable configuration to generate chemical pathways between metal centers present in metalloproteins.

\section{Importancia de las fuerzas de bottom-up y top-down como estructuradores del fitoplancton en lagunas aluviales con diferentes tipos de conexión al río Paraná Medio}

\section{Diego Germán Frau}

diegogf@live.com.ar

Directora: Dra. Susana José de Paggi

Co-Director: Dr. Rodrigo Sinistro

Lugar de realización: Instituto Nacional de Limnología (UNL-CONICET)

Fecha de defensa: 24 de noviembre de 2016
La importancia de los modelos funcionales así llamados bottom-up y top-down como estructuradores de las comunidades acuáticas ha sido estudiada en los últimos 30 años especialmente en sistemas templados. En sistemas acuáticos subtropicales, componentes de los valles aluvia- 
les de ríos de llanura, el pulso hidrológico se constituye también en un factor de control de reconocida relevancia. Existen pocos estudios en que ambos factores de regulación (bottom-up/top-down y pulso hidrológico) sean analizados de forma simultánea ponderando la importancia relativa que tiene el pulso en lagunas con diferentes tipos de conexión al sistema fluvial. Por esta razón, esta tesis tuvo por objetivo explorar a partir de diferentes enfoques (análisis de campo y experiencias de microcosmos) la importancia que tiene el pulso hidrológico en una laguna con conexión vertical y otra con conexión lateral como disruptor de los efectos de bottom-up y top-down; atendiendo particularmente al efecto que tienen los depredadores sobre la estructura del fitoplancton. Se tomaron muestras de fitoplancton, diferentes depredadores asociados (zooplancton, peces y el mejillón mitílido de origen asiático Limnoperna fortunei Dunker) y se midieron diferentes variables ambientales incluidos los nutrientes (nitritos-nitratos y ortofosfatos) con frecuencia mensual en dos lagunas conectadas (una lateral y la otra verticalmente) al sistema del río Paraná Medio. Se realizaron además dos experiencias de microcosmos en términos de evaluar la capacidad de depredación de diferentes fracciones de zooplancton (micro, meso y macrozooplancton), peces planctívoros y L. fortunei. Los resultados mostraron baja riqueza, elevado biovolumen y dominancia de euglenoideos en la laguna con conexión vertical y alta riqueza, bajo biovolumen y dominancia de criptofíceas en la laguna con conexión lateral. En ambas lagunas la entrada de agua al sistema mostró ser un factor de control, más importante en la laguna con conexión lateral. Fueron la conductividad, los nutrien- tes y la abundancia de cladóceros (laguna conexión vertical) y la temperatura, conductividad y turbidez (laguna conexión lateral) los principales factores de control identificados en el análisis de redundancia (RDA). La experiencia de microcosmos mostró que los peces omnívoros (Cheirodon interruptus Jenyns especie dominante en ambas lagunas) no afecta significativamente al fitoplancton, en tanto que el meso y macrozooplancton (cladóceros y copépodos) son capaces de constituirse como factores de control -en ausencia de peces- cuya intensidad depende del tamaño del depredador y además de la forma, tamaño y características de la pared celular de las algas. L. fortunei también muestra una selectividad que depende de la forma, el tamaño, las características de la pared celular y la presencia de rotíferos como recurso alimentario palatable y accesorio. Se concluye que la importancia de los factores de control bottomup y top-down ciertamente sería mayor en las lagunas con conexión vertical, estando las lagunas con conexión lateral gobernadas principalmente por las variaciones en el pulso hidrológico.

\section{Importance of bottom-up and top-down forces as phytoplankton structurers in allu- vial shallow lakes with different types of connection to the Middle Paraná River}

The importance of bottom-up and topdown as controlling factors of aquatic communities has been studied in the last 30 years, especially in temperate systems. In subtropical systems, governed by Floodplain Rivers, the hydrological pulse is also identified as a control factor. Nonetheless, there are few studies that analyzed the relevance of both regulatory factors (bottom-up/ top-down and hydrological pulse) in alluvial 
lakes with different kinds of connection to the river system. For this reason, this thesis aimed to explore from different approaches (field analysis and microcosm experiences) the importance of the hydrological pulse in two shallow lakes (one with vertical connection and another with lateral connection to the Middle Paraná River system) as disruptor of bottom-up and top-down; attending particularly, to the effect of different predators on phytoplankton structure. Phytoplankton samples, different associated predators (zooplankton, fish and Limnoperna fortunei Dunker (mytilid mussel of Asiatic origin)), and different environmental parameters including nutrients (nitrite-nitrate and orthophosphate concentrations) were monthly taken in the two shallow lakes. Two microcosm experiences were also made in terms of assessing the ability of different fractions of zooplankton (micro, meso and macrozooplankton), planktivorous fish and $L$. fortunei to control phytoplankton. The results showed low richness, high biovolume and euglenoids dominance in the lake with vertical connection and high richness, low biovolume and cryptophyceans dominance in the lake with lateral connection. In both lakes water entering to the system showed to be a controlling factor, but it was more important in the lake with lateral connection. Conductivity, nutrient concentration and the abundance of cladocerans (vertically connected lake) and temperature, conductivity, and turbidity (laterally connected lake) were the main control factors identified in the redundancy analysis (RDA). The experience of microcosm showed that omnivorous fish (Cheirodon interruptus Jenyns, the dominant species in both lakes) does not significantly affect phytoplankton, while the meso and macrozooplankton (cladocerans and copepods) are capable of exerting -in absence of fish- a controlling factor, which will depend on predator size and furthermore shape, size and algae cell-wall characteristics. L. fortunei also showed a selectivity that depends on the shape, size, and cellwall characteristics of algae and the presence of rotifers as accessory palatable food source. It is concluded that the importance of the bottom-up and top-down would be greater in those lakes with vertical connection to the river system, while the lakes with lateral connection would be primarily governed by variations in the hydrological pulse.

\section{Efecto de la exposición a compuestos agro-industriales sobre la vitelogénesis y las características histo-funcio- nales del oviducto de Caiman latirostris}

\section{Germán Hugo Galoppo}

ggaloppo@fbcb.unl.edu.ar

Directora: Dra. Mónica Muñoz-de-Toro

Co-Directora: Dra. Cora Stoker

Lugar de realización: Instituto de Salud y Ambiente del Litoral. Facultad de Bioquímica y Ciencias Biológicas. Universidad Nacional del Litoral
Fecha de defensa: 23 de Noviembre de 2016

El yacaré overo (Caiman latirostris) es una especie altamente sensible a la exposición de sustancias capaces de alterar la homeostasis del sistema endocrino, llamadas perturbadores endocrinos (PEs). El bisfenol A (BPA) es un PE con acción estro- 
génica y antiandrogénica ampliamente presente en el medioambiente. En Caiman latirostris (C. latirostris) el tracto reproductor femenino (TRF) u oviducto es un órgano hormonodependiente cuya maduración se completa postnatalmente. En mamíferos, la diferenciación postnatal del TRF está regulada por moléculas de la vía de señalización wnt. Por otra parte, la vitelogénesis es un proceso estrógeno-dependiente que solo se observa en hembras postpuberales. La hormomodependencia del oviducto y la vitelogénesis ubica a ambos como posibles blancos de acción de PEs. Dados estos antecedentes, nuestra hipótesis general fue "La exposición postnatal temprana a compuestos clasificados como PEs induce vitelogénesis hepática y modifica las características histofuncionales del oviducto de C. latirostris prepuberales". En el presente trabajo, en primer lugar completamos la caracterización histofuncional del oviducto, desde neonatos a juveniles, estableciendo los patrones de expresión témporo-espacial de moléculas representativas de la vía de señalización wnt (WNT-5a, WNT-7a y $\beta$-catenina). Además establecimos la relación entre el grado de diferenciación oviductal evaluado por score histofuncional, -definido en trabajos previos- y la expresión de estas moléculas. El patrón de expresión de WNT-7a y WNT-5a sugiere la existencia de un mecanismo de regulación recíproca similar al propuesto en ratones y ambas moléculas mostraron correlación significativa con el grado de desarrollo oviductal evaluado por el score histofuncional. La expresión de $\beta$-catenina no se modificó en los diferentes estadíos madurativos ni mostró correlación con el grado de desarrollo oviductal. Nuestros resultados sugieren que la vía de señalización wnt interviene en la diferenciación postnatal del oviducto de $C$. latirostris a través de una vía no-canónica ( $\beta$-catenina independiente).

En segundo lugar, evaluamos los efectos a nivel oviductal y sobre la vitelogénesis de la exposición postnatal temprana a BPA. Hembras de yacaré overo se expusieron a dos dosis subcutáneas de BPA $(1,4$ o 140ppm), vehículo (aceite de maíz) o $17 \beta$ estradiol (E2), (0,014 o 1,4ppm) los días postnatales 26 y 33. Los animales se sacrificaron a los 40 días de edad y se extrajeron muestras de plasma, oviducto e hígado. Todos los tratamientos modificaron la histoarquitectura oviductal, observándose aumento de la altura epitelial, desorganización del colágeno y aumento en el grosor y organización de la capa muscular. Respecto a la histofuncionalidad, todos los tratamientos, a excepción de E2 0,014ppm produjeron un aumento del score histofuncional. Tanto E2 1,4ppm como BPA 1,4ppm produjeron aumento de la actividad proliferativa y disminución en la expresión de $E R \alpha$, mientras que la exposición a BPA 140ppm aumentó la expresión de ER $\alpha$. Los niveles de expresión de PR no se modificaron como consecuencia de los tratamientos. Estos cambios en la histoarquitectura e histofuncionalidad se acompañaron con cambios en la expresión de WNT-7a y de WNT5a. Estos resultados muestran cambios en el patrón temporal de diferenciación morfogenética del tubo uterino de $C$. latirostris como consecuencia de la exposición a BPA que involucrarían a miembros de la vía de señalización wnt y que junto al aumento de score histofuncional sugieren un adelantamiento de la maduración oviductal.

Finalmente, para evaluar los efectos de la exposición a BPA sobre la vitelogénesis, se estudió la transcripción del gen que codi- 
fica para VTG (vtg), la VTG almacenada en el hepatocito y la VTG en circulación periférica. Como consecuencia de la exposición a E2 1,4ppm observamos inducción de vitelogénesis a nivel de mRNA, depósitos de VTG in situ y niveles circulantes de VTG; mientras que la exposición a BPA 1,4ppm produjo aumento de los niveles plasmáticos de VTG. Esto demuestra que tanto E2 1,4ppm como BPA 1,4ppm indujeron vitelogénesis y que la exposición postnatal a dosis ambientalmente relevantes de BPA activa este proceso en hembras inmaduras. La VTG circulante fue el biomarcador más sensible para detectar exposición a PEs en los tiempos elegidos.

Los resultados de esta tesis aportan conocimiento acerca de las vías involucradas en la diferenciación del oviducto de $C$. latirostris, así como el adelantamiento del proceso de maduración oviductal como consecuencia de la exposición postnatal temprana a PEs, alertando sobre posibles efectos que pueden afectar su función reproductiva. Finalmente, convalida a la detección de VTG circulante como una herramienta útil para la detección de exposición a contaminantes ambientales con acción estrogénica.

Effects of agro-industrial compounds on vitellogenesis and oviductal histofunctional features of Caiman latirostris

Caiman latirostris is a crocodilian species highly sensitive to endocrine disrupting compounds (EDCs) pollution, being early stages of development critical periods of exposure. Bisphenol A (BPA) is an environmentally relevant EDC. In Caiman latiros- tris, the female reproductive tract (FRT) is an estrogen-dependent organ that completes its differentiation postnatally. In mammals, this process is controlled by members of wnt proteins signaling pathway. Additionally, vitellogenesis is an estrogen-dependent process characteristic of mature females. The aims of this study were: 1)- to characterize the ontogenic changes in wnt signaling molecules expression establishing its relationship with FRT development, evaluated by an scoring system; and 2)- to assess the effects of early postnatal exposure to 17 - $\beta$-estradiol (E2) or BPA on vitellogenesis and histofunctional features of the FRT. Wnt protein expression pattern suggests a mutual regulation between wnt7a and wnt5a. Wnt-7a and wnt-5a expressions significantly correlate with FRT development suggesting that this process is controlled by wnt signaling pathway. Early postnatal FRT was highly sensitive to E2 or BPA. Increased luminal epithelial height and higher proliferative activity were observed in E2 and BPA groups. Changes in the scoring system, steroid hormone receptors; collagen remodeling and muscle-associated proteins suggest a precocious FRT histofunctional differentiation in E2 or BPA exposed caimans. Environmentally relevant doses of BPA induced vitellogenesis in immature female caimans. These results provide evidence on Caiman latirostris FRT postnatal differentiation pathways and EDCs-induced changes. In addition, we propose the study of vitellogenesis in immature female caimans as a tool to monitor estrogen-like EDCs exposure. 


\section{Sobre el Almacenamiento del Carbono en Células Autótrofas y Heterótrofas. Caracterización cinética y estructural de enzimas del metabolismo de azúcares y azúcares-alcoholes}

\section{Matías Daniel Hartman}

mdhartman@fbcb.unl.edu.ar

Director: Dr. Alberto Álvaro Iglesias

Lugar de realización: Instituto de Agrobiotecnología del Litoral. Laboratorio de Enzimología Molecular, Cátedra de Bioquímica Básica de Macromoléculas. Facultad de Bioquímica y Ciencias Biológicas. Universidad Nacional del Litoral

Fecha de defensa: 10 de marzo de 2016

Las plantas son organismos sésiles que deben gatillar respuestas múltiples frente a un medio ambiente continuamente cambiante; para integrar dichas respuestas, el metabolismo primario es finamente modulado. El carbono fijado fotosintéticamente es particionado a distintos niveles: a nivel intracelular, puede ser utilizado para la síntesis de almidón o, como triosas fosfato, puede ser exportado hacia el citosol. En dicho compartimento, el principal fotosintato producido a partir de triosas fosfato es la sacarosa (Suc). Por otra parte, la partición intercelular del carbono se da cuando dicho disacárido se dirige a los tejidos nofotosintéticos para suplirlos de esqueletos carbonados. Si bien la mayoría de las plantas producen Suc, un grupo de plantas de interés agronómico y comercial (manzano, peral, duraznero, ciruelo, entre otras) producen glucitol (Gol) como fotosintato primario, el cual es sintetizado en el citosol y luego exportado a los tejidos no-fotosintéticos, junto con la Suc. Es evidente que en estas especies vegetales existe un grado mayor de complejidad en cuanto a la partición del carbono a nivel intra e intercelular.

La síntesis citosólica del Gol está mediada por dos enzimas, la aldosa-6-fosfato reductasa (Ald6PRasa) y la Gol-6-fosfato fosfatasa, las cuales convierten la glucosa-6-fosfato en Gol. Una vez que es descargado en el tejido no fotosintético, el Gol es oxidado a fructosa por una Gol deshidrogenasa (GolDHasa) y es la Fru la cual ingresa en las distintas vías metabólicas en el fruto. Debido a que en los últimos años los estudios realizados en rosáceas se han focalizado a la expresión de los genes que codifican para las enzimas del metabolismo del Gol en distintos tejidos y en distintas condiciones y a la obtención de las enzimas y su caracterización bioquímica básica, existe un déficit en cuanto al estudio de la regulación de estas enzimas por modificaciones pos-traduccionales. En este trabajo de tesis nos centramos en el estudio de las enzimas Ald6PRasa y la GolDHasa presentes en hojas y frutos de duraznero (Prunus persica) obtenidas de manera; como así también otras proteínas que participan en la regulación pos-traduccional de las primeras.

Caracterizamos la Ald6PRasa y encontramos que la enzima es inhibida por azúcares-fosfato y por Pi. La actividad de la Ald6PRasa disminuyó en una manera dependiente del tiempo y de la concentración de compuestos oxidantes; tanto el H2O2 como la diamida inactivaron la 
enzima, de manera irreversible. La oxidación llevó a la desestabilización de la enzima induciendo la formación de agregados proteicos, correlacionado directamente con la pérdida de actividad enzimática. Sin embargo, dicho proceso podría ser modulado y atenuado por la glutationilación dependiente de GSSG. En su conjunto los resultados sugieren que, frente a situaciones oxidantes y debido a la resistencia a la oxidación de la Ald6PRasa, la producción de Gol podría ser mantenida, permitiendo que este actúe como osmoprotector (tanto in situ como también a larga distancia. El flujo de carbono dirigido hacia la síntesis del poliol sólo disminuiría bajo perturbaciones extendidas del estado redox intracelular como consecuencia de la inactivación de la Ald6PRasa. En dicho escenario, la síntesis de Gol tendría un rol secundario y los sustratos no utilizados, Glc6P o NADPH, podrían ser redirigidos hacia metabolismos que permitirían combatir el estrés.

Caracterizamos la GolDHasa bioquímicamente y encontramos que los metales pesados inhibieron totalmente a la enzima, lo cual sugiere que existirían residuos de Cys involucrados en tal proceso. Distintas moléculas oxidantes y alquilantes inhibieron la enzima de manera reversible, ya que el agregado de GSH o tiorredoxinas (TRX) recuperaron la inactivación. Nuestros resultados nos llevan a proponer un escenario metabólico en el cual, bajo condiciones normales, la GolDHasa se encontraría activa y el Gol acumulado o descargado en tejidos heterotróficos (frutos) se convertiría en Fru, con la producción concomitante de $\mathrm{NADH}$. Sin embargo, en condiciones que producen un ambiente oxidativo, la actividad de la GolDHasa disminuiría debido a su oxidación, llevando a la acumulación de Gol.
La reversión de esta situación dependería de los niveles de GSH y de TRX reducida, lo cual está ligado a una situación opuesta de un ambiente intracelular reductor. Los resultados sugieren que en un ambiente oxidante se acumularía Gol, protegiendo a la célula de las especies oxidantes dañinas producto del estrés. Una vez que el balance redox se restablece, los agentes reductores como GSH o TRX podrían reducir a la GolDHasa y permitir el flujo normal del carbono.

\section{About Carbon Storage within Auto- trophic and Heterotrophic Cells. Kinetic and structural characterization of sugars and sugar-alcohols metabolism enzymes.}

Plants are complex organisms that must integrate internal responses and external stimuli to coordinate its development, finely regulating both synthesis and use of carbon. In most plants, fixed carbon is partitioned within cells between starch and sucrose; the latter, can be translocated to sink tissues for carbon supplying. In a small number of plant species, along with sucrose and starch, polyols are produced (glucitol) as primary photosynthates. These, also act as osmotic regulators and free radical scavengers against stress situations. In this work, we studied how posttranslational modifications modulate the activity of the main enzymes related to glucitol metabolism in peach: aldose-6-phosphate reductase (Ald6PRase, glucitol synthesis) and glucitol dehydrogenase (GolDHase, glucitol catabolism). Ald6PRase was inhibited by sugar phosphates and inorganic phosphate, also by oxidants. With our results, it is tempting to speculate that polyol synthesis would not be affected under oxidative conditions, due to Ald6PRase is highly resistant to oxidative molecules, even more, it could be glu- 
tathionylated, protecting the enzyme. Under severe stress conditions, the enzyme would be inactivated, whereas NADPH could feed antioxidant systems. Gol catabolism in non-photosynthetic tissues would be rapidly downregulated under oxidative stress conditions, due to the high sensibility of GolDHase to oxidants. When redox balance is restored, GolDHase could be reactivated by thioredoxins, allowing normal carbon flux. Altogether, under stress conditions glucitol could exert protective functions not only in its synthesis site but also at long distance. Overall, both transcriptional and posttranslational regulation of glucitol enzymes would operate in the same direction in plants.

\section{Secado spray aplicado al desarrollo de cultivos probióticos a partir de cepas de lactobacilos autóctonas}

\section{Luisina Lavari}

luisinalavari@hotmail.com

Director: Dr. Gabriel Vinderola

Co-Directora: Dra. Roxana Paez

Lugar de realización: Laboratorio de Calidad de Leche y Agroindustria, INTA EEA Rafaela; Área de Procesamiento de Alimentos, INLAIN (UNL- CONICET); Facultad de Bioquímica y Ciencias Biológicas, Universidad Nacional del Litoral.

Fecha de defensa: 5 de julio de 2016.

La investigación y el desarrollo de ingredientes funcionales (probióticos, prebióticos, ácidos grasos poliinsaturados, entre otros) son actualmente un importante foco de desarrollo en la industria alimentaria. En este contexto, la producción de microorganismos probióticos autóctonos para su incorporación a alimentos funcionales resulta de potencial interés científico para la industria de alimentos. En este sentido, uno de los desafíos de la industria alimentaria hoy es producir cultivos probióticos nacionales deshidratados a bajo costo.

En este trabajo se abordó el desarrollo de un cultivo probiótico autóctono deshidratado por secado spray con potencial tecnológico y funcional para ser utilizado en alimentos o suplementos funcionales. En una primera etapa se evaluó el potencial tecnológico de tres cepas de lactobacilos pertenecientes a la colección del INLAIN: L. paracasei Jp1, L. rhamnosus 64 y L. gasseri 37, y la posibilidad de usar suero de queso como medio de crecimiento y como matriz de secado. Por su capacidad de desarrollar en subproductos lácteos (suero de quesería, suero de ricota, permeado de suero) como medios de cultivo de bajo costo, y por su resistencia al secado spray, se seleccionó $L$. rhamnosus 64 para ensayos posteriores en los cuales se estudió la utilización de permeado de suero de queso como medio de cultivo, la aplicación de distintas condiciones de estrés para mejorar la resistencia intrínseca de la cepa al secado spray, y el uso de distintas matrices de secado (suero de queso combinado con almidón, WPC, maltodextrina o goma arábiga). La suplementación de permeado de suero con extracto de levadura, triptona, Tween 80, Mg-Mn permitió la producción (en anaerobiosis y a $\mathrm{pH}$ controlado) de L. rhamnosus 64. Los resultados obtenidos hasta este punto, junto a algunos aspectos prácticos que podrían condicionar un futuro esca- 
lado (facilidad de manejo de los ingredientes, disponibilidad, solubilidad, costo, entre otros), fueron considerados en conjunto para elegir un tratamiento de estrés moderado y una matriz para el secado por pulverización. En particular, la aplicación de un estrés térmico moderado previo al secado spray tuvo un efecto positivo sobre la viabilidad celular durante la conservación del cultivo deshidratado a largo plazo.

Para evaluar la funcionalidad de L. rhamnosus 64, se realizaron estudios en animales de laboratorio, donde se evaluó el efecto del secado spray sobre la capacidad probiótica de la cepa y el comportamiento frente a modelos de salmonelosis e inflamación intestinal. En un modelo de inmunoestimulación, L. rhamnosus 64 se administró de forma oral, como cultivo fresco y secado spray. La cepa en estudio demostró ser capaz de estimular las defensas intestinales. Por otro lado, el tratamiento tecnológico aplicado modificó la expresión de estos parámetros y de los perfiles de citoquinas. También se evaluó el potencial de $L$. rhamnosus 64 frente a modelos murinos de patologías intestinales. Si bien en un ensayo de salmonelosis la cepa en estudio no demostró efectos protectores en este modelo, como cultivo secado spray sí se observó un efecto protector frente a la colitis inducida por TNBS. La evaluación macroscópica de los tejidos permitió observar que los animales tratados con el cultivo secado spray presentaron un grado de inflamación menor que los tratados con el cultivo fresco y que los del grupo control. Si bien los resultados son preliminares y debería profundizarse el estudio, se observó que la administración de L. rhamnosus 64 como cultivo secado spray, podría tener un papel moderador de procesos inflamatorios intestinales.
En su conjunto, los resultados obtenidos sugieren que L. rhamnosus 64 posee potencial tecnológico para desarrollarse utilizando medios de cultivo económicos a partir de subproductos lácteos y ser producido mediante secado spray. Esta tecnología es adecuada y económica para la conservación ciertas bacterias probióticas y permite también la utilización de suero de queso, enriquecido con ingredientes tales como almidón, maltodextrina o concentrado de proteínas de suero como material de pared para su uso en alimentos funcionales. Además los resultados obtenidos en los estudios funcionales in vivo demuestran su robustez frente al secado spray, manteniendo la capacidad de estimular la función inmune. Los resultados de este trabajo de tesis permitieron avanzar en el conocimiento sobre el potencial de la deshidratación por secado spray para el desarrollo de cultivos probióticos utilizando cepas autóctonas y una tecnología de deshidratación ampliamente disponible en nuestro país en todas las etapas del escalado desde el laboratorio hasta el nivel industrial.

\section{Spray drying applied to the develop- ment of probiotics cultures from auto- chthonous lactobacilli strains.}

The aim of this work was to develop a spray-dried autochthonous probiotic culture, with technological and functional potential to be used in functional food or supplements. In a first stage, three strains of lactobacilli from the INLAIN collection were studied: L. paracasei Jp1, L. rhamnosus 64 and L. gasseri 37. Their technological potential was evaluated, with emphasis on using cheese whey as culture medium and as thermoprotectant or carrier for spray drying. Due to its capacity to develop in 
dairy media (cheese and ricotta whey and whey permeate) and its resistance to spray drying, L. rhamnosus 64 was selected for further studies. The biomass production in whey permeate supplemented with different ingredients was optimized. Also, the effect of mild stresses to improve the intrinsic resistance of the strain to spray drying and the use of different carriers (cheese whey combined with starch, WPC, maltodextrin and arabic gum) were studied. The functional characteristics of $L$. rhamnosus 64 were studied in in vivo models, in particular the effect of spray drying on its functional properties. The strain showed, in different experimental models, to be able to stimulate the gut mucosa immune response.

The results of this work allowed us to go forward on the knowledge about the potential of dehydration by spray drying for the development of probiotic cultures using a technology which is widely available in our country from the laboratory to the industrial level.

\section{Dinámica de especies químicas de importancia ecológica en el sistema del Río Paraná Medio: influencia de las fases hidrológicas y relaciones con el fitoplancton}

\section{Gisela Paola Mayora}

giselamayora@hotmail.com

Directora: Dra. María dos Santos Afonso

Co-Directora: Dra. Melina Devercelli

Lugar de realización: Instituto Nacional de Limnología. Laboratorio de Plancton y Laboratorio de Química. Facultad de Bioquímica y Ciencias Biológicas. Universidad Nacional del Litoral

Fecha de defensa: 14 de marzo de 2016

El funcionamiento de los grandes ríos con llanura aluvial es regulado por el pulso hidrosedimentológico, que influencia la dinámica de los materiales disueltos y particulados, lo cual repercute sobre la biota. En el río Paraná Medio, los pulsos hidrológicos y sedimentológicos suelen desacoplarse temporalmente, permitiendo identificar los efectos de cada uno. El objetivo de esta tesis fue evaluar la dinámica de nutrientes y materia orgánica disuelta (MOD) en el sistema del Paraná Medio, conside- rando el efecto de las fluctuaciones hidrológicas y sedimentológicas y las relaciones con el fitoplancton. Para ello, se muestrearon ambientes con diferente conectividad al cauce principal durante dos fases de aguas bajas (la primera de ellas coincidente con el pulso de sedimentos) separadas por una fase de aguas altas.

Tanto el pulso sedimentológico como el hidrológico influyeron en los patrones espacio-temporales de las variables estudiadas. El primero aportó sales, $\mathrm{NH}_{4}^{+}$, fósforo reactivo soluble (PRS) y sólidos suspendidos (incluyendo $\mathrm{N}$ y $\mathrm{P}$ ), e incrementó las pérdidas de $\mathrm{NO}_{2}^{-}, \mathrm{NO}_{3}^{-}, \mathrm{N}$ orgánico disuelto (NOD) y C orgánico disuelto (COD) probablemente debido a su adsorción y remoción por microorganismos sobre las partículas suspendidas. Durante la inundación, aumentó el aporte de sílice disuelto por la cuenca del Paraná Superior; mientras que llanura removió $\mathrm{N}$ inorgánico disuelto (NID) y fue una fuente de PRS, NOD y MOD cro- 
mofórica (MODC). Finalmente, la clorofilaa aumentó durante la limnofase exenta del pulso sedimentológico. La inundación disminuyó la heterogeneidad espacial, mientras que el pulso de sedimentos disminuyó la heterogeneidad de la conductividad e incrementó la del clima lumínico y clorofila-a.

La importancia relativa de la turbidez y el color del agua (directamente relacionado con la concentración de MODC) varió de acuerdo a las fases, y se relacionó con la especiación de nutrientes y la biomasa del fitoplancton. El cociente turbidez/color fue menor durante la potamofase y limnofase exenta del pulso de sedimentos en ambientes con baja conectividad hidrológica; mientras que los mayores valores ocurrieron durante el pulso de sedimentos en ambientes más conectados al río. La turbidez se asoció positivamente a las proporciones de $\mathrm{P}$ y $\mathrm{N}$ particulados y de $\mathrm{NH}_{4}{ }^{+}$respecto a las concentraciones totales de $\mathrm{P}$ y $\mathrm{N}$; y negativamente a las proporciones de otros nutrientes disueltos. El color se asoció positivamente a las proporciones de PRS, $\mathrm{P}$ orgánico disuelto (POD) y NOD, y negativamente a la de NID. En ambientes aislados, la biomasa del fitoplancton se asoció positivamente con la turbidez (que habría aumentado al resuspenderse sedimentos conteniendo células algales).

La calidad de la MODC se asoció con la actividad enzimática, estructura y estado fisiológico del fitoplancton (evaluado a través del cociente Feo/Clo). La actividad de la fosfatasa alcalina asociada a partículas algales (APA) aumentó en los ambientes más aislados de la planicie, relacionándose positivamente con la acidez de la MODC. Los grupos funcionales ácidos de la MODC podrían aumentar la mineralización de los compuestos orgánicos fosforados al estimular la síntesis de la enzima por disminución de la biodisponibilidad de $\mathrm{PO}_{4}^{3-}$. $\mathrm{La}$ MODC de mayor peso molecular se relacionó positivamente con la densidad de fitoflagelados mixotróficos y negativamente con grupos fototróficos. Asimismo, en lagunas aisladas, se asoció positivamente con el cociente Feo/Clo. Esto sugiere que la MODC de mayor peso molecular repercute tanto en la estructura del fitoplancton como en el estado fisiológico de las células algales. Dado que el cociente Feo/Clo se asoció negativamente con el nivel hidrométrico, la inundación habría tenido un efecto rejuvenecedor sobre el fitoplancton.

Puede concluirse que la planicie aluvial y el pulso de sedimentos no sólo remueven y aportan materiales, sino que también favorecen su transformación afectando su especiación. Esto respondería al aumento del tiempo de residencia del agua en la llanura y, durante el pulso de sedimentos, a la elevada disponibilidad de superficies donde las reacciones químicas pueden ocurrir. Por lo tanto, las alteraciones de la conectividad río-llanura aluvial y del pulso de sedimentos pueden afectar el funcionamiento ecológico del Paraná Medio y de ambientes ubicados aguas abajo que reciben los materiales exportados. Finalmente, en ambientes sujetos a fluctuaciones en la calidad de la MODC, esta variable debería ser considerada para estudiar la dinámica del fitoplancton.

Dynamic of chemical species with ecological importance in the system of the Middle Paraná River: influence of the hydrological phases and relations with phytoplankton

In the Middle Paraná River, hydrological and sedimentological regimes are uncoupled allowing to identify the effects of each 
one on chemical species and biota dynamics. The aim of this thesis was to assay the dynamics of nutrients and dissolved organic matter (DOM) in the Middle Paraná system, considering the effect of hydrological and sedimentological fluctuations and the relations with phytoplankton. The sediment pulse supplied salts, ammonium, soluble reactive phosphorus, and particulate nutrients; but incremented other dissolved nitrogen forms and dissolved organic carbon (DOC) removals. During high waters, the floodplain constituted a source of soluble reactive phosphorus, DOC, chromophoric DOM (CDOM), and dissolved organic nitrogen; whereas the Upper Paraná increased silica supply. The flood decreased the spatial heterogenity in the main channelfloodplain gradient. The sediment pulse decreased the heterogenity of conduc- tivity but increased light environment and chlorophyll-a heterogeneities. Phytoplanktonic biomass was negatively affected by the flood and the sediment pulse. Finally, CDOM quality was associated to phosphatase alkaline activity, structure and physiological state of phytoplankton. It can be concluded that the floodplain and the sediment pulse not only affect the input and remotion of materials, but also their transformation probably due to increaments in water residence time and surfaces where reactions occur. Therefore, modifications of the riverfloodplain connectivity and the sediment pulse can affect the ecological functioning of the Middle Paraná River and downstream environments receiving exported materials. Finally, CDOM appear as an important factor that should be taken into account for evaluating phytoplankton development.

\section{Amplicones y partículas replicantes defectivas derivadas del virus Herpes simplex tipo 1 como vectores transgénicos de proteínas de patógenos de humanos y animales}

\section{Carlos Adolfo Palacios}

c_a_palacios@yahoo.com

Directora: Dra. Nora Mattion

Co-director: Dr. Juan Claus

Lugar de realización: Instituto de Ciencia y Tecnología Dr. César Milstein (ex CEVAN), CONICET, Saladillo 2468 (1440) Ciudad de Buenos Aires

Fecha de defensa: 26 de agosto de 2016.

Los vectores basados en el virus Herpes simplex tipo 1 (HSV-1) se presentan como un sistema de gran potencial tanto en terapia génica, como en vacunas de última generación. Recientemente, se han desarrollado diferentes sistemas de vectores virales basados en HSV-1, los que se han utilizado en ensayos clínicos para el tratamiento de tumores en humanos, y como vacunas contra diferentes patógenos.

En el presente trabajo, se evaluó el uso de distintos tipos de vectores basados en HSV-1, como candidatos para el establecimiento de una plataforma de vacunas de nueva generación contra diferentes patógenos humanos y animales, a través de la expresión de antígenos pertenecientes a Rotavirus (RV) grupo A y grupo C, la ric- 
kettsia Anaplasma marginale, y el Virus de la Fiebre Aftosa.

Se construyeron vectores herpéticos defectivos y de tipo amplicón para la expresión de las proteínas de RV NSP4, VP2, VP4, VP6 y VP7, de manera individual, o en construcciones dobles, portando los genes VP2 y VP6, o VP4 y VP7 de RV grupo A. Adicionalmente se trabajó con un vector para la expresión de la proteína VP6 de RV grupo $\mathrm{C}$, de una cepa no cultivable. Para la rickettsia Anaplasma marginale, se construyó un vector amplicón para la expresión de la proteína de superficie MSP5.

En el caso del Virus de la Fiebre Aftosa, se ensayó un vector viral capaz de presentar en la superficie de la partícula un epitope inmunodominante de la proteína VP1, denominado RGD, responsable de interactuar con el receptor celular. Para esta estrategia, el vector viral fue modificado para insertar el epitope RGD en la secuencia que codifica para el gen de la glicoproteína C de HSV-1.

Por medio de transducción o infección de cultivos celulares con estos vectores, se pudo comprobar la expresión de los antígenos heterólogos en los diferentes sistemas.

Se seleccionaron algunos de los vectores obtenidos para realizar una prueba de concepto sobre su uso como agentes vacunales, generando los stocks de cantidad y calidad necesarios, para aplicar los diferentes planes de inmunización en animales de experimentación, y así poder evaluar la respuesta inmune específica generada. De este modo se utilizaron los vectores que expresan la proteína VP6 de RV grupo C, VP4 de RV grupo A, y MSP5 de A. marginale, para evaluar la respuesta inmune inducida luego de su inoculación a ratones Balb/c, como modelo de experimentación.
Los resultados indicaron que los vectores herpéticos fueron capaces de generar una respuesta inmune específica. En el caso de los antígenos de RV analizados, se estudió el desarrollo de una respuesta inmune humoral, y en el caso del vector que codifica para MSP5 de A. marginale, se determinó una respuesta inmune principalmente celular, la cual se balanceó hacia una respuesta múltiple luego del suministro de un refuerzo con el antígeno proteico adyuvado.

Además, otro de los principales logros de este trabajo ha sido el establecimiento de los protocolos de producción de diferentes vectores virales para su uso como inmunógenos.

Teniendo en cuenta los resultados obtenidos en el presente trabajo, se demuestra que vectores basados en HSV-1 son candidatos atractivos para el desarrollo de vacunas genéticas de nueva generación, dirigidas contra patógenos virales y bacterianos que afectan a humanos y animales.

HSV-1 based amplicon vectors and defective viruses as transgenic vectors for proteins from human and veterinary pathogens

Herpes simplex virus type 1 (HSV-1) based vectors have shown a great potential for gene therapy and are considered promising vehicles to deliver heterologous antigens for new generation vaccines.

In the present work, HSV-1 viral vectors have been evaluated for the assessment as a vaccine vector platform against group A and group C rotavirus (RV), the rickettsia Anaplasma marginale, and Foot-and-mouth disease virus (FMDV) infections.

Defective herpesviruses and amplicon vectors that express, individually or co-expressing, group A RV proteins were 
developed. Additionally, amplicon vectors which express VP6 protein from a non-cultivable group $C R V$ strain or the surface antigen MSP5 of A. marginale were constructed.

A display vector, which expresses in its surface the FMDV-RGD epitope of the structural protein VP1, was generated.

Stocks of the selected amplicon vectors, expressing group A RV VP4 and VP7, or A. marginale MSP5 were produced to carry out different immunization schedules in Balb/c mice, to assess the specific immune response elicited, in the absence of adjuvants.
The results showed an induction of specific immune responses in the vaccinated animals. The development of specific humoral immune response was obtained with amplicon vectors expressing RV proteins. A cellular immune response was mainly observed after inoculation of the $A$. marginale MSP5 amplicon vector, which shifted to a multiple immune response when boosted with the homologous adjuvanted recombinant protein.

The results presented in this work indicate that HSV-1 amplicon vectors are attractive candidates for the development of safe genetic vaccines against human and animal pathogen infections.

\section{Diversidad y evolución de las inflorescencias en las subtribus más derivadas de Cynodonteae (chloridoideae-poaceae)}

\section{Vanesa Pilatti}

vanesapilatti@hotmail.com

Director: Dr. Abelardo Carlos Vegetti Co-Directora: Dra. Renata Reinheimer Lugar de realización: Cátedra de Morfología Vegetal. Facultad de Ciencias Agrarias. Universidad Nacional del Litoral.

Fecha de defensa: 22 de Marzo de 2016

El linaje más derivado de la tribu Cynodonteae está constituido por las subtribus Monanthochloinae, Hilariinae, Boutelouinae, Scleropogoninae y Muhlenbergiinae. Sus especies se caracterizan por presentan una gran diversidad morfológica en inflorescencias, espiguillas y flores. Sin embargo, no existen trabajos que describen las estructuras reproductivas y los procesos de desarrollos involucrados en la diversificación de las inflorescencias en un contexto evolutivo.
Es por eso que se realizó un estudio morfológico comparativo de las inflorescencias adultas de 91 especies abarcando la mayoría de los géneros presentes en las subtribus. Considerando que las estructuras adultas son el resultado final de un programa de desarrollo, se realizó un estudio comparativo del desarrollo de inflorescencia, espiguilla y flor utilizando imágenes de microscopía electrónica de barrido (MEB) de 17 especies pertenecientes al linaje en estudio. Para entender la evolución de la morfología de las inflorescencias, se realizaron reconstrucciones ancestrales de los caracteres de inflorescencia mediante los métodos Máxima Parsimonia e Inferencia Bayesiana. Los resultados obtenidos demuestran que varios caracteres morfológicos y procesos tipológicos podrían explicar la diversidad aparente que presentan 
las inflorescencias adultas. Por otro lado, se identificaron diferentes patrones de desarrollo en el sistema de ramificación de la inflorescencia y en espiguilla. Además, se reconocieron diversos patrones de desarrollo floral que determinan la sexualidad de la flores. El estudio filogenético muestra que el linaje más derivado de Cynodonteae y las subtribus que lo conforman son monofiléticos. La reconstrucción ancestral del carácter presencia/ausencia de florescencia principal muestra una clara tendencia hacia inflorescencias que pierden la florescencia principal en grupos derivados. Sin embargo, los análisis de reconstrucción ancestral de los caracteres homogenización, grado de ramificación y tipo de inflorescencia mostraron varias tendencias evolutivas, debido a que son caracteres propensos a cambiar entre los diferentes estados. En conclusión, las inflorescencias del linaje más derivado de Cynodonteae resultaron ser un grupo de estudió muy interesante debido a la gran diversidad morfológica que presentan las estructuras adultas y a los diversos procesos de desarrollo que se encuentran involucrados en la formación de dichas estructuras reproductivas. Al analizar la morfología de las inflorescencia desde una perspectiva evolutiva, podemos concluir que varias tendencias evolutivas debieron ocurrir para originar la diversidad de inflorescencias presente en linaje estudiado.

Inflorescence diversity and evolution of the most derived subtribes within Cynodonteae (chloridoideae-poaceae)

The most derived lineage within Cynodonteae is constituted by Monanthochloi- nae, Hilariinae, Boutelouinae, Scleropogoninae and Muhlenbergiinae subtribus. Their species are characterized by having a large morphological diversity in inflorescence, spikelet and flower. However, there are not studies that describe the reproductive structures and development processes involved in the diversification of the inflorescence in an evolutionary context. For this reason, the objectives of this thesis are: 1) to study the morphology of adult inflorescences of 91 species, 2) to perform a comparative development study of inflorescence, spikelet and flower of 17 species using images of scanning electron microscopy and 3) to evaluate ancestral reconstructions of inflorescence characters using the Maximum Parsimony and Bayesian Inference methods. Seven morphological characters and eight typological processes could explain the apparent diversity in adult inflorescences. Variations between different development patterns were identified in the inflorescence branching system, spikelet and flower. The most derived lineage of Cynodonteae and the subtribes that comprise it were monophyletic. The ancestor of the group could have been a non-truncated inflorescence that lost the main florescence in derivatives groups. Ancestral reconstruction of characters homogenization, degree of branching and type of inflorescence showed several evolutionary trends, because they are characters likely to change between different states. In conclusion, the diversity that presents the studied inflorescences is the result of morphological and developmental changes occurred during the evolution of the lineage. 


\section{Factores fisiológicos que modulan la esteroidogénesis hipocámpica}

\section{María Florencia Rossetti}

mfrossetti@fbcb.unl.edu.ar

Director: Dr. Jorge Guillermo Ramos

Co-Director: Dra. Jorgelina Varayoud

Lugar de realización: Instituto de Salud y Ambiente del Litoral; Departamento de Bioquímica Clínica y Cuantitativa. Facultad de Bioquímica y Ciencias Biológicas. Universidad Nacional del Litoral

Fecha de defensa: 09 de marzo de 2016

El objetivo general de este trabajo fue estudiar, mediante el uso de modelos in vivo, el efecto de la edad, la experiencia reproductiva y el ambiente enriquecido sobre la regulación transcripcional de las enzimas esteroidogénicas en el hipocampo de la rata. Para dicho análisis se cuantificaron los niveles de ARNm (mediante la reacción en cadena de la polimerasa (PCR) en tiempo real) y se comparó el estado de metilación de las regiones regulatorias presentes en las secuencias promotoras de cada uno de los genes (utilizando enzimas de restricción sensibles a metilación y posterior PCR en tiempo real).

Para determinar el efecto de la edad sobre la neuroesteroidogénesis hipocámpica, se utilizaron ratas hembra y macho de la cepa Wistar en día post-natal (DPN) 90 (jóvenes adultas) y 450 (adultos mayores). Previo a su sacrificio, los animales fueron evaluados en el test de memoria episódica. Según nuestros resultados, el aumento de la edad disminuyó significativamente la transcripción de las moléculas StAR, P450scc, 3 $\alpha$-HSD, 3 $\beta$-HSD, $5 \alpha$-reductasa-1, $\quad P 450(11 \beta)-2, \quad P 450(17 \alpha)$,
P450arom y $17 \beta$-HSD-3 y aumentó el estado de metilación de determinados sitios CpG de los promotores de P450scc, $5 \alpha$-reductasa- 1 y $3 \alpha-H S D$ en el hipocampo de las ratas hembra, pero no de las ratas machos. El envejecimiento, además, afecto negativamente la performance de las ratas hembra y macho en el test de memoria episódica. Cuando se compararon animales jóvenes se observó mayor expresión génica de StAR, P450scc, $3 \alpha$-HSD, 3 3 -HSD, $5 \alpha$-reductasa-1, P450 (17 $\alpha)$ y $17 \beta-H S D-3$ en las hembras comparadas con los machos. También se detectaron diferencias a nivel cognitivo en el test de memoria empleado.

Para evaluar el efecto del ambiente enriquecido sobre la regulación transcripcional de las enzimas neuroesteroidogénicas se utilizaron ratas hembra en DPN 90 y 450 expuestas durante 10 y 105 días a ambientes con estimulación motora y estimulación sensorial. La exposición breve a ambientes estimulados sensorialmente generó en el hipocampo de las ratas jóvenes un aumento en la expresión del ARNm de las enzimas $3 \alpha-H S D, 5 \alpha$-reductasa-1 y P450 (17 $\alpha$ ) y una disminución de P450arom. Sumado a ello, disminuyó el estado de metilación de uno de los sitios CpG del promotor de la enzima $5 \alpha$-reductasa-1. Por su parte, la exposición breve a ambientes con estimulación motora aumentó la expresión génica de las enzi-

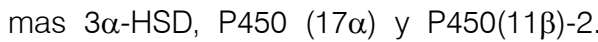
En cuanto a la estimulación sensorial prolongada, la misma fue capaz de atenuar la caída en la transcripción de ciertas enzimas neuroesteroidogénicas asociada a 
la edad, incrementando la expresión de ARNm de StAR, 3 $\alpha$-HSD, $5 \alpha$-reductasa- 1 y P450(17 $\alpha)$ en el hipocampo de ratas adultas. Sumado a ello, el ambiente enriquecido disminuyó el estado de metilación de uno de los sitios CpG del promotor de la enzima $5 \alpha$-reductasa-1, lo que podría explicar los mayores niveles de ARNm encontrados.

En la última etapa, se estudió el efecto de la preñez y la lactancia sobre la expresión génica de las enzimas neuroesteroidogénicas y los mecanismos regulatorios intervinientes. Para ello, se compararon ratas adultas de 15 meses de edad sometidas a 3 preñeces completas con sus respectivas lactancias y sin ellas frente a ratas vírgenes de la misma edad. Según nuestros resultados, los sucesivos ciclos de preñez y lactancia incrementaron la transcripción de las enzimas P450scc, 5 $\alpha$-reductasa-1, P450arom y P450(11ß)-2) y disminuyeron el estado de metilación del promotor correspondiente al gen de la enzima $5 \alpha$-reductasa- 1 en las ratas adultas. La preñez en ausencia de lactancia también incremento la expresión génica de las proteínas P450scc y $5 \alpha$-reductasa- 1 ; sin embargo, disminuyó los niveles de ARNm de P450arom y P450 ( $\beta 11)-2$. Sumado a ello, disminuyó el estado de metilación de los promotores de P450scc y 5 $\alpha$-reductasa-1 y aumentó el del gen correspondiente a la enzima P450arom.

Estos hallazgos contribuyen con el estudio de los mecanismos moleculares implicados en los efectos negativos asociados al envejecimiento y el rol de los tratamientos conductuales como factores atenuantes de dichos efectos.

Physiological factors that modulate hippocampal steroidogenesis

The aim of this thesis was to determine the effects of age, reproductive experience and enriched environment on the gene expression of StAR, P450scc, 3 $\beta-H S D, 3 \alpha-H S D$, $5 \alpha$-reductase- $1, \quad P 450(17 \alpha), \quad P 450(11 \beta)-2$, $17 \beta$-HSD-3 and P450arom in the rat hippocampus. To analyze the effects of aging, Wistar male and female rats at post-natal day (PND) 90 (young adult) and PND 450 (aged) were used. According to our results, aging has negative effects on episodic-like memory and modifies the transcription of the genes that are involved in the synthesis of neurosteroids, decreasing the methylation state of P450scc, $5 \alpha$-reductase- 1 and $3 \alpha-H S D$ promoters. Moreover, sexual dimorphism was found in the expression of steroidogenic molecules in young and aged animals.

To evaluate the effects of environmental enrichment, Wistar female rats at PND 90 and PND 450 were exposed during 10 and 105 days to environmental with sensory and motor stimulation. Short-term exposure to environments with sensory and motor stimulation modifies the expression of steroidogenic enzymes in the hippocampus of young and aged rats. Moreover, long-term exposure to an environment with sensory stimulation attenuates the age-related decline in the mRNA expression of steroidogenic enzymes. In addition, short- and long-term exposure to environments with sensory stimulation decreased the methylation levels of the $5 \alpha$-reductase- 1 promoter.

Finally, we compared nulliparous and multiparous rats at PND 450 subjected to three pregnancies with and without their respective lactation and we found that pregnancy and lactation differentially modifies the transcription of steroidogenic enzymes, changing the methylation state of P450scc, 5 $\alpha$-reductase-1 and P450arom promoters. 


\section{Estructura trófica del bentos de sistemas río-laguna de la llanura aluvial del río Paraná Medio a través de análisis de dieta e isótopos estables del carbono y nitrógeno}

\section{Miguel Saigo}

miguelsaigo@gmail.com

Directora: Dra. Mercedes Marchese

Co-director: Dr. Karl Matthias Wantzen

Lugar de realización: Instituto Nacional de Limnología (INALI-CONICET-UNL)

Fecha de defensa: 15 de marzo de 2016

El objetivo de la tesis fue abordar el estudio de las comunidades biológicas del río Paraná medio desde la perspectiva de la ecología funcional. En primer término se analizó la variación de los rasgos biológicos de las especies bentónicas de cuatro ambientes representativos del sistema. Dicho análisis indicó que las características físicas de los cuerpos de agua determinan el set de rasgos biológicos de las especies residentes. Tal resultado plantea la posibilidad de que un doble gradiente de inestabilidad ambiental sea un factor estructurador de los ensambles bentónicos. Por otra parte se clasificó a las especies bentónicas dominantes en grupos funcionales tróficos mediante un análisis de dieta y solapamiento de nicho. La mayor parte de las taxa estudiadas fueron clasificadas como colectores recolectores. Asimismo, se utilizó el análisis de proporciones isotópicas para determinar la importancia relativa de las fuentes de carbono en el sistema durante el ciclo hidrológico. Los resultados de dicho análisis apuntan a que en las lagunas desconectadas las variaciones del nivel hidrométrico provocan variaciones drásticas en la importancia relativa de las fuen- tes. Finalmente se construyó un modelo de trama trófica incluyendo productores primarios, invertebrados y peces. Sobre dicho modelo se estimaron los parámetros: nivel trófico medio, longitud de cadena y omnivoría. Tales parámetros resultaron relativamente bajos lo cual siguiere que en el sistema del Paraná medio existen mecanismos de control de las tramas tróficas que aún deben ser analizados

Trophic structure of the benthos of riverlake systems in the Middle Paraná river floodplain by means of diet and stable isotopes analysis of carbon and nitrogen.

The thesis aimed to analyze the biological communities of the Middle Paraná river from the functional ecology approach. Firstly, we analyzed the biological traits variations of benthic species in four representative habitats of the river system. This analysis indicated that physical features of the habitat acts as environmental filter for benthic invertebrates. This result suggests that a double gradient of environmental instability could be a structuring factor of benthic assemblages. Moreover, we classified benthic taxa into functional feeding groups by means of gut content and niche overlap analysis. Most of studied species were classified as gatherer collectors. Likewise, we used stable isotopes analysis to determine the relative importance of carbon sources along the hydrologic cycle. The results of this analysis showed that in temporarily connected lakes the hydrologic fluctuations drive dras- 
tic changes in the relative importance of carbon sources. Finally, we constructed a food web model including primary producers, invertebrates and fishes. On the basis of this model we estimated the parameters: Mean trophic level, food chain length and omnivory. These parameters turned out to be relatively low, suggesting that in the paraná system there are food web controllers that remain to be analyzed.

\section{Efectos de la exposición perinatal a perturbadores endocrinos sobre el desarrollo ovárico y la fertilidad de la hembra}

\section{Clarisa Guillermina Santamaría \\ clarisa_santamaria@hotmail.com \\ Director: Dr. Horacio A. Rodríguez \\ Co-director: Dr. Enrique H. Luque \\ Lugar de realización: Instituto de Salud y Ambiente del Litoral (UNL-CONICET). Laboratorio de Endocrinología y Tumo- res Hormono-dependientes. Facultad de Bioquímica y Ciencias biológicas. Universi- dad Nacional del Litoral \\ Fecha de defensa: 16 de marzo de 2016}

Nuestra hipótesis general de trabajo postula que la exposición a químicos clasificados como xenoestrógenos (Xe) en períodos hormono-sensibles del desarrollo induce alteraciones en procesos críticos del desarrollo normal de las gónadas y el tracto reproductor femenino, impactando negativamente en la capacidad reproductiva en la vida adulta. Entre los Xe más utilizados estudiamos al bisfenol A (BPA) y al dietilestilbestrol (DES).

Capítulo 1. Disfunciones ováricas en ratas adultas nacidas de madres tratadas con bajas dosis de BPA por vía oral. En este capítulo demostramos que hembras adultas nacidas de madres tratadas con bajas dosis de BPA (50 $\mu \mathrm{g} / \mathrm{kg}$.día y 0,5 $\mu \mathrm{g} / \mathrm{kg}$.día) por vía oral durante la gestación y la lactancia poseen disfunciones ováricas. Estas disfunciones comprenden un menor reclutamiento inicial asociado a un desbalance en la expresión del receptor de andrógenos (RA) entre los folículos primordial/primario y un mayor número de cuerpos lúteos (CL) (indicio de incremento en el número de ovocitos ovulados), junto con mayores niveles de progesterona sérica. Estos resultados muestran que el BPA es capaz de afectar los estadíos tempranos del desarrollo ovárico con consecuencias en la edad adulta.

Capítulo 2. Efectos del BPA sobre la respuesta ovárica al tratamiento con gonadotrofinas exógenas en ratas. En este capítulo estudiamos la respuesta ovárica a un tratamiento con gonadotrofinas exógenas, en ratas inmaduras, nacidas de madres tratadas con BPA por vía oral durante el período perinatal. Pudimos observar un mayor desarrollo folicular luego del tratamiento con PMSG en los ovarios de las hembras expuestas a BPA50 durante el período perinatal. Este estímulo en la foliculogénesis se evidencia por un incremento de la subpoblación de folículos antrales chicos. Este incremento en el desarrollo folicular estuvo asociado a mayor expresión de FSHR y LHR, de las enzimas esteroidogénicas Cyp17 y Cyp19, así como también de 
RA y RE $\beta$. En base a estos cambios, pensamos que la exposición a BPA en etapas tempranas de la vida prenatal y postnatal causa una mayor susceptibilidad de los folículos ováricos a la acción de la FSH. La respuesta a hCG se tradujo en una mayor incidencia de folículos atrésicos sin cambios en la ovulación, con un menor tamaño de CL. Nuestros resultados muestran que la exposición perinatal a BPA, condiciona la capacidad de respuesta del ovario a un tratamiento con gonadotrofinas exógenas.

Capítulo 3. Acción del BPA en el ensamblado folicular en cultivos de ovarios enteros. Nuestro objetivo fue profundizar el estudio de los efectos directos del BPA sobre la formación de folículos primordiales, en cultivos de ovarios enteros. Los ovarios expuestos in vitro a E2 o BPA mostraron un mayor porcentaje de ovocitos no ensamblados en folículos primordiales y una menor expresión de Foxl2 en los ovarios expuestos a BPA. Estos resultados nos permiten concluir que el BPA actuaría de manera similar a E2, inhibiendo la ruptura de los nidos de células germinales y el posterior ensamblado folicular en cultivos de ovarios enteros, sugiriendo que lo hace a través de la menor expresión de Foxl2. Estos resultados en conjunto, agregan evidencia a la capacidad de BPA de impactar de forma directa sobre procesos tempranos del desarrollo ovárico.

Capítulo 4. La exposición neonatal a xenoestrógenos altera la respuesta ovárica al tratamiento con gonadotrofina en corderas. Corderas prepúberes expuestas a BPA o DES durante los primeros 14 días de vida posnatal tienen un escaso desarroIlo folicular y bajos niveles de estradiol en respuesta al tratamiento con oFSH, relacionando esta menor capacidad de respuesta del ovario a FSH exógena con anomalías en la expresión de GDF-9.

Los resultados detallados en esta tesis doctoral fundamentan la preocupación mundial por la creciente exposición a estrógenos ambientales, y demuestran que el desarrollo folicular y la síntesis esteroidogénica ováricas son un blanco de acción constante de los mismos.

Effects of perinatal exposure to endocrine disruptors on ovarian development and female fertility

In this doctoral thesis our general hypothesis postulates that exposure to chemicals classified as xenoestrogens in hormone-sensitive developmental periods induces alterations in critical processes of the normal development of the gonads and the female reproductive tract, negatively impacting reproductive capacity in adulthood. We studied two of the most used xenoestrogens, Bisphenol A (BPA) and Diethylstilbestrol (DES).

In Chapter 1: Ovarian dysfunctions in adult rats born to mothers treated with Iow doses of oral BPA, our results show that BPA is able to affect the early stages of ovarian development with consequences in adulthood. In Chapter 2: Effects of BPA on ovarian response to exogenous gonadotropins treatment in rats, we demonstrated that perinatal exposure to BPA, conditions the ovary's responsiveness to exogenous gonadotropins treatment. In Chapter 3: Action of BPA on follicular assembly in whole ovary cultures, we demonstrated that in both rats and OCT4-GFP mice, BPA is able to directly impact the follicular assembly. Finally in Chapter 4: we demonstrate that neonatal exposure to xenoestrogens alters the ovarian response to gonadotropin treatment in lambs. 
The results detailed in this doctoral thesis are based on the worldwide concern about the increasing exposure to environmental estrogens, and demonstrate that the follicu- lar development and steroidogenic ovarian synthesis are a constant target of the xenoestrogens.

\section{Estructura electrónica e interacciones magnéticas en complejos de metales de transición con ligandos de interés biológico}

\section{Rosana Patricia Sartoris}

rosanasartoris@gmail.com

Director: Dr. Rafael Calvo

Co-Director: Dra. Mireille Perec

Lugar de realización: Departamento de Física. Facultad de Bioquímica y Ciencias Biológicas. Universidad Nacional de Litoral Fecha de defensa: 06 de abril de 2016

Reportamos un estudio magneto estructural de cinco compuestos dinucleares de $\mathrm{Cu}^{\prime \prime}$ unidos por puentes pirofosfatos. Tres de ellos, $\left[\mathrm{Cu}_{2} \text { (terpy) }\right)_{2}\left(\mathrm{HP}_{2} \mathrm{O}_{7}\right)\left(\mathrm{H}_{2} \mathrm{PO}_{4}\right)\left(\mathrm{H}_{3} \mathrm{PO}_{4}\right)$ $\left(\mathrm{H}_{2} \mathrm{O}\right)$ ] ,1, (terpy $=2,2^{\prime}: 6^{\prime}, 2^{\prime \prime}$-terpiridina, bpa $=2,2$ '-bipiridilamina and bipy=2,2'-bipiridina), $\left[\mathrm{Cu}_{2}(\mathrm{bpa})_{2}\left(\mathrm{P}_{2} \mathrm{O}_{7}\right)\left(\mathrm{H}_{2} \mathrm{O}\right)_{2}\right] \cdot 2.5 \mathrm{H}_{2} \mathrm{O}, 2 \mathrm{y}$ $\left[\mathrm{Cu}(\mathrm{bpa})\left(\mathrm{H}_{2} \mathrm{P}_{2} \mathrm{O}_{7}\right)\right]_{2}$, son nuevos; fueron sintetizados y su estructura cristalina determinada por difracción de rayos $X$ en monocristal. Otros dos, previamente reportados: $\left[\mathrm{Cu} \text { (bipy) }\left(\mathrm{H}_{2} \mathrm{P}_{2} \mathrm{O}_{7}\right)\right]_{2} \cdot 3\left(\mathrm{H}_{2} \mathrm{O}\right), 4$, cuya estructura cristalina fue refinada, y [Cu(bipy) $\left.\left(\mathrm{H}_{2} \mathrm{P}_{2} \mathrm{O}_{7}\right)\right]_{2}, 5$, bipy $=2,2$ '-bipiridine, fueron añadidos a los anteriores. Los cinco compuestos son triclínicos, grupo espacial $\mathbf{P} \overline{1}$ , y contienen unidades dinucleares de Cull unidos por aniones pirofosfatos. Espectros de resonancia paramagnética electrónica (RPE) fueron estudiados en muestras de monocristal con el campo magnético $\boldsymbol{B}_{0}$ en tres planos perpendiculares, en función de la orientación de $\boldsymbol{B}_{0}$ a $293 \mathrm{~K}$, para los compuestos $1,3,4$ y 5 , y a $T=4.7,50$ y $293 \mathrm{~K}$ para el compuesto 2 . También fueron estudiados los espectros en función de la temperatura $(T)$ entre $\sim 4$ y $293 \mathrm{~K}$ para una orientación fija de $\boldsymbol{B}_{0}$ en cada uno de los cinco compuestos. En los compuestos 1, 3, 4, y 5 los espectros muestran una única resonancia para toda orientación del campo y a temperaturas $T$ entre 4 y $293 \mathrm{~K}$, como en un sistema mononuclear de espines, sin estructura hiperfina. Las matrices $\boldsymbol{g}$ calculadas son discutidas en términos de las estructuras moleculares. La dependencia con la temperatura de la intensidad de la señal de RPE observada por encima de $4 \mathrm{~K}$ muestra un comportamiento de Curie (paramagnético) indicando que $\left|J_{0}\right|<2$ $\mathrm{K}$ (definiendo $\mathrm{H}_{\text {ex }}=-J_{0} S_{1} \cdot S_{2}$ ), sin estructuras derivadas de acoplamientos hiperfinos o interacciones de intercambio intradinuclear. La ausencia de estructura hiperfina y splitting dinuclear de las unidades se explica considerando procesos de angostamiento por intercambio, donde la interacción de intercambio interdimuclear destruye las interacciones dipolares y de intercambio anisotrópico intradinuclear. El modelo usado permite establecer un límite inferior de las interacciones entre unidades dinucleares vecinas. Los espectros de RPE obser- 
vados en el compuesto 2 muestran una rica estructura dependiente de $T$. Por debajo de $\sim 8 \mathrm{~K}$ los espectros se asignan a dos tipos de defectos cristalinos mononucleares de cobre acoplados a dos núcleos de nitrógeno. Las matrices $\boldsymbol{g}$ y los acoplamientos hiperfinos observados a esa $T$ proporcionan información acerca de las estructuras de los defectos. Por encima de $10 \mathrm{~K}$ los espectros están dominados por la respuesta dinuclear del material, mostrando interacciones hiperfinas con dos núcleos de cobre. La estructura de los espectros colapsa a un solo pico por encima de 18 $\mathrm{K}$ cuando las unidades están magnéticamente conectadas, y el comportamiento magnético se convierte en 3D. Los resultados obtenidos por encima de $10 \mathrm{~K}$ en el compuesto 2 se atribuyen a una interacción de intercambio intradinuclear AFM $\left(J_{0}=-28\right.$ (3) $\mathrm{cm}^{-1}$, y a un acoplamiento de intercambio tres órdenes de magnitud más débil $\left|J_{1}\right| \sim 0.022 \mathrm{~cm}^{-1}$ entre iones Cull de unidades dinucleares vecinas. Se discuten las interrelaciones entre la estructura, el acoplamiento de intercambio, la dimensión magnética y la dinámica de espines.

Electronic structure and magnetic interactions in transition metal complexes with ligands of biological interest

We report a magneto-structural study of five pyrophosphate-bridged $\mathrm{Cu}^{\prime \prime}$ complexes: $\quad\left[\mathrm{Cu}_{2}\right.$ (terpy) ${ }_{2}\left(\mathrm{HP}_{2} \mathrm{O}_{7}\right)\left(\mathrm{H}_{2} \mathrm{PO}_{4}\right)$ $\left.\left(\mathrm{H}_{3} \mathrm{PO}_{4}\right)\left(\mathrm{H}_{2} \mathrm{O}\right)\right]$ 1, terpy $=2,2^{\prime}: 6^{\prime}, 2^{\prime \prime}$-terpy- ridine, $\left[\mathrm{Cu}_{2}(\mathrm{bpa})_{2}\left(\mathrm{P}_{2} \mathrm{O}_{7}\right)\left(\mathrm{H}_{2} \mathrm{O}\right)_{2}\right] \cdot 2.5 \mathrm{H}_{2} \mathrm{O} \quad 2$, $\left[\mathrm{Cu}(\mathrm{bpa})\left(\mathrm{H}_{2} \mathrm{P}_{2} \mathrm{O}_{7}\right)\right]_{2}$ 3, bpa $=2,2^{\prime}$-bipyridylamine, $\quad\left[\mathrm{Cu}(\text { bipy })\left(\text { cis- } \mathrm{H}_{2} \mathrm{P}_{2} \mathrm{O}_{7}\right)\right]_{2} \cdot 3\left(\mathrm{H}_{2} \mathrm{O}\right)$ 4, and $\left[\mathrm{Cu}\left(\text { bipy) }\left(\text { trans }-\mathrm{H}_{2} \mathrm{P}_{2} \mathrm{O}_{7}\right)\right]_{2} 5\right.$, bipy $=$ 2,2'-bipyridine. The EPR spectra were collected in three planes of single crystal samples as a function of the orientation of the magnetic field $\boldsymbol{B}_{0}$ and as a function of temperature $(T)$ between $\sim 4$ and $293 \mathrm{~K}$ for fixed orientations of $\boldsymbol{B}_{0}$. In the compounds $\mathbf{1 , 3}, \mathbf{4}$ y $\mathbf{5}$ the EPR spectra display a single resonance for any field orientation and temperature $(T)$ between 4 and $293 \mathrm{~K}$, without hyperfine structure. The calculated $g$-matrices are discussed in terms of the molecular structures and of the results for Cull ions in related compounds. The temperature dependences of the intensity of the EPR signals observed above $4 \mathrm{~K}$ display a paramagnetic Curie behavior, indicating that $\left|J_{0}\right|<2 \mathrm{~K}$, with no structure arising from hyperfine coupling or intradinuclear exchange interactions. The EPR signals observed below $\sim 8 \mathrm{~K}$ the spectra are assigned to two types of mononuclear crystal defects of mononuclear copper. The $g$-matrices and hyperfine couplings at these $T$ provide information about the structures of the defects. We attribute the results above 10 $K$ to the interplay of an AFM intradinuclear exchange interaction $J_{0}=-28(3) \mathrm{cm}^{-1}$ and $\left|J_{1}\right| \sim 0.022 \mathrm{~cm}^{-1}$ between Cull ions in neighbor dinuclear units. The interplays between structure, exchange couplings, magnetic dimension and spin dynamics in the dinuclear compound are discussed. 


\section{Péptidos bioactivos de origen microbiano de interés para el desarrollo de alimentos funcionales}

\section{Pablo Gabriel Spontón}

pgsponton@gmail.com

Director: Dr. Arturo Simonetta

Co-Directora: Dra. Georgina Tonarelli

Lugar de realización: Cátedras de Microbiología y Biotecnología, Departamento de Ingeniería en Alimentos, Facultad de Ingeniería Química, Universidad Nacional del Litoral y Laboratorio de Péptidos Bioactivos, Departamento de Química Orgánica, Facultad de Bioquímica y Ciencias Biológicas, Universidad Nacional del Litoral.

Fecha de defensa: 30 de Noviembre de 2016.

En la actualidad se asume plenamente que los alimentos pueden aportar compuestos bioactivos para el organismo humano, proporcionar beneficios para la salud y reducir el riesgo de padecer ciertas enfermedades. Péptidos bioactivos encriptados en las estructuras de proteínas se generan usualmente in vivo por acción de enzimas gastrointestinales, o pueden también obtenerse in vitro con enzimas específicas, y/o producirse durante los procesos biotecnológicos de elaboración de determinados alimentos. Los péptidos bioactivos pueden ejercer su efecto sobre los sistemas cardiovascular, digestivo, inmunológico y/o nervioso. En este trabajo se propuso estudiar y evaluar in vitro la actividad inhibitoria frente a la enzima acetilcolinesterasa (AChE) y a la enzima convertidora de angiotensina (ECA), así como la actividad antimicrobiana, tanto de hidrolizados de manoproteínas obtenidos por hidrólisis enzimática como de hidrolizados proteicos obtenidos de cul- tivos de bacterias ácido lácticas (BAL) y levaduras, en soluciones de caseínas y del producto (hidrolizado) comercial NZ-Case Plus. Además, los objetivos del trabajo también incluyeron fraccionar y caracterizar los hidrolizados que presentaron las propiedades bioactivas más interesantes.

Por un lado, se obtuvieron 5 extractos de manoproteínas desde 5 cepas de levaduras por extracción térmica y posterior separación por Concanavalina $A$ y diálisis. Cada extracto se hidrolizó con diferentes enzimas comerciales y la capacidad proteolítica se confirmó por electroforesis en gel de poliacrialamida con dodecil sulfato de sodio (SDS-PAGE) y por determinación del grado de hidrólisis $(\mathrm{GH})$. La actividad inhibitoria de todos los extractos hidrolizados de manoproteínas frente a ECA fue nula o baja, con valores de inhibición que no superaron el 20 $\%$. La actividad antimicrobiana se determinó frente a bacterias Gram (+) y Gram (-). Se observó inhibición frente a la cepa de Listeria monocytogenes tipo I DTUNLu 328, con un halo de inhibición máximo de $14 \mathrm{~mm}$ de diámetro, y Bacillus cereus DBFIQ B 28, con un halo de inhibición máximo de $18 \mathrm{~mm}$ de diámetro. Se evaluó el modo de acción de estos extractos inhibidores mediante el estudio de la cinética de crecimiento o muerte de las cepas blanco. Los extractos manoproteínicos de la cepa de Candida blankii LTW7 y de la cepa de Pichia anomala LTW6, ambos hidrolizados con tripsina, presentaron un efecto bacteriostático sobre las poblaciones celulares proliferantes de las cepas de B. cereus DBFIQ B 28 y de $L$. 
monocytogenes tipo I DTUNLu 328, respectivamente. El screening de la actividad antiacetilcolinesterasa permitió observar una variada actividad inhibitoria, con un máximo de inhibición del $59 \%$. Se seleccionaron los 6 extractos más activos y a cada uno de ellos se le determinó la concentración inhibitoria 50, siendo el extracto de $S$. cerevisiae DBFIQ L2 hidrolizado con pepsina/quimotripsina el que presentó el menor valor $\left(6,8 \mathrm{mg} \mathrm{ml}^{-1}\right)$. El fraccionamiento de los 6 extractos manoproteínicos seleccionados por cromatografía de fase reversa permitió obtener 6 fracciones con actividad inhibitoria importante frente a AChE, siendo la mayor actividad inhibitoria de $64 \%$. Dichas fracciones se analizaron por métodos cromatográficos y espectrométricos. Se pudo comprobar la presencia de péptidos principalmente hidrofílicos, cuyo peso molecular estuvo comprendido entre 700 y 4800 Da. Además, se determinó la presencia de azúcares en todas las fracciones, siendo manosa el azúcar mayoritario. Las fracciones más activas se purificaron por cromatografía de afinidad, obteniéndose dos nuevas fracciones: una fracción peptídica (FP) y una fracción glicopeptídica (FGP). Todas las FPs y FGPs presentaron actividad inhibitoria frente a AChE, y las FGPs exhibieron mayor capacidad de inhibición que las FPs, con valores de actividad comprendidos entre 49,3 y $77,8 \%$.

En lo que respecta a los hidrolizados proteicos (HP) libres de células, el método de obtención resultó adecuado en todos los casos. La hidrólisis tanto de la caseína como del sustrato comercial NZ-Case Plus por parte de todas las cepas de BAL y levaduras fue confirmada tanto por SDS-PAGE como por $\mathrm{GH}$. La actividad inhibitoria frente a ambas enzimas, tanto AChE como ECA, fue nula o baja. Ninguno de los HP presentó actividad antimicrobiana frente a las cepas bacterianas ensayadas.

Los resultados obtenidos en este trabajo de Tesis evidencian que la hidrólisis de manoproteínas obtenidas a partir de cepas de levaduras provenientes de ecosistemas alimentarios regionales, condujo a la formación de una gran cantidad y variedad de péptidos y/o glicopéptidos con propiedades antimicrobianas y antiacelticolinesterásicas, aunque carentes de propiedades antihipertensivas considerables. La actividad anti-AChE, sumada a la actividad antimicrobiana, los hacen potencialmente aptos para ser utilizados como aditivos alimentarios funcionales y/o como agentes terapéuticos.

\section{Bioactive peptides of microbial origin of interest for the development of func- tional foods.}

The aim of this Thesis was to study the enzyme inhibitory activities against acetylcholinesterase (AChE) and angiotensin converting enzyme (ACE) of peptides and glycopeptides produced by enzymatic hydrolysis of mannoproteins, isolated from different yeast strains. The antimicrobial activity of hydrolysated of mannoproteins and hydrolysates obtained from cultures of lactic acid bacteria and yeasts $(\mathrm{PH})$ from casein and commercial hydrolysed NZCase Plus solutions were also investigated.

The Inhibitory activity of all hydrolysated mannoproteins extracts against ACE was nil or low. Antimicrobial activity against Listeria monocytogenes type I DTUNLu 328 and Bacillus cereus DBFIQ B28 strains was only observed. Mannoprotein extracts showed a bacteriostatic effect on the proliferating cell populations of the strains of $B$. cereus and $L$. 
monocytogenes, respectively. A wide inhibitory activity against AChE was observed, with a maximum inhibition of $59 \%$. Fractionation of the selected mannoprotein extracts by reverse-phase chromatography allowed obtaining 6 fractions with significant inhibitory activity against AChE. Peptides mainly hydrophilic, with molecular weight in the range of 700 to $4800 \mathrm{Da}$, were detected. The presence of sugars in all fractions was determined. The most active fractions were separated by affinity chromatography. Results demonstrated that glycopeptide fractions showed greater inhibition against AChE than peptide fractions, with activity values ranging between 49.3 and $77.8 \%$.

The inhibitory activity of $\mathrm{PH}$ against both enzymes, either AChE or ACE, was nil or low. None of the $\mathrm{PH}$ presented antimicrobial activity against the bacterial strains tested.

As final conclusion, we can say that antiaceltycholinesterase property, together with the antimicrobial activity, make the bioactive peptide fractions from yeast's mannoproteins potentially suitable for use as functional food additives and/or as therapeutic agents.

\section{Decápodos dulceacuícolas del Paraná medio: relación entre la dinámica de las poblaciones y del río en una escala metapoblacional}

\section{María Victoria Torres}

mavictoriatorres@gmail.com

Director: Dr. Pablo Agustín Collins

Co-Director: Dr. Fernando Roberto Momo

Lugar de realización: Laboratorio de Macrocrustáceos, Instituto Nacional de Limnología (CONICET-UNL). Facultad de Bioquímica y Ciencias Biológicas. Universidad Nacional del Litoral

Fecha de defensa: 29 de marzo de 2016

Las fluctuaciones hídricas de los sistemas con llanura aluvial conectan el cauce principal del río y la zona de inundación promoviendo el intercambio de nutrientes y organismos entre ambientes lóticos y leníticos. Las poblaciones de decápodos dulceacuícolas están ajustadas a la dinámica hídrica que presenta el río Paraná, mostrando ordenamiento y distribución espacial gobernados por factores físicos, químicos y biológicos. Los movimientos y conectividad de las poblaciones de los crustáceos del río Paraná presentan ciertas dificultades en su estudio debido a las dimensiones del sistema y visibilidad. Estos se pueden evaluar a partir de las variaciones del fenotipo de los individuos, y el flujo génico entre las poblaciones. Además, estudios de dinámica poblacional, a partir de la estimación de la abundancia y los métodos de marca-recaptura de organismos pueden ser útiles para estimar dichos patrones. Asimismo, las poblaciones de decápodos en ambientes de planicie de inundación pueden ser explicadas en términos metapoblacionales. El objetivo de la presente tesis fue describir y analizar la dinámica metapoblacional de decápodos dulceacuícolas en relación a las fluctuaciones hídricas del río Paraná Medio y sus afluentes. Entre las dinámicas evaluadas, se analizaron los cambios y la estructura poblacional en distintos sitios en diferentes períodos del río. Además, se estimaron movi- 
mientos de decápodos entre poblaciones en distintos períodos del río, a partir de variaciones genéticas y de forma, y en lagunas conectadas y aisladas temporalmente. Las escalas espaciales micro y mesogeográficas se consideraron de acuerdo a las distancias entre los sitios muestreados en los ríos (alejados y cercanos). La abundancia de camarones y cangrejos de agua dulce cambió con las micro-fluctuaciones de los ríos: M. borellii y Trichodactylus borellianus aumentaron en aguas con tendencia a bajar y $P$. argentinus en aguas bajas. Además, las variaciones poblacionales dependieron de la presencia o ausencia de la vegetación acuática flotante o arraigada y de las variables de espacio (sitios): M. borellii y T. borellianus fueron más abundantes en sitios con vegetación flotante libre, mientras que $P$. argentinus en sitios con aguas libres y vegetación arraigada. Estas variaciones mostraron un patrón inverso entre las abundancias de $M$. borellii y $T$. borellianus con $P$. argentinus que dependieron de las micro-fluctuaciones, presencia de vegetación y temperatura. Los tamaños de las especies variaron en relación a las micro-fluctuaciones ocurridas en el año. Por ejemplo, las mayores tallas y hembras ovígeras se registraron predominantemente cuando el río comienza a bajar y en aguas bajas, coincidiendo con la estación de primavera. Los movimientos de decápodos fueron indicados en ríos conectados, considerando una escala microgeográfica a partir de las similitudes entre el fenotipo de los individuos. Un intercambio menor de decápodos ocurrió cuando la distancia entre los sitios aumentó (escala mesogeográfica). Esto indicó una mayor relación entre cambios en el fenotipo y ubicación geográfica de los sitios observados. Las relaciones entre las formas de individuos fueron diferen- tes en momentos distintos del ciclo hídrico (micro-fluctuaciones hídricas) indicando posibles movimientos en relación a la dinámica del río. En cuanto a las variaciones de forma interpoblacionales en cada especie se observó algún tipo de dispersión diferencial entre los distintos morfotipos estudiados, en relación a la historia de vida y tipo de locomoción. Las poblaciones del camarón $M$. borellii de los sitios alejados, considerando una escala mesogeográfica, estuvieron levemente estructuradas genéticamente. Esto determinó la existencia de flujo génico entre poblaciones y niveles altos de heterocigosis. La densidad poblacional de los camarones M. borellii y $P$. argentinus variaron acorde a las fases de conexión de las lagunas con el sistema lótico adyacente. Además, la densidad poblacional fue diferente considerando la interacción de los dos camarones y fases de conexión. En relación a los tamaños de los camarones, estos fueron más grandes cuando la densidad poblacional fue menor. Las variaciones en el tamaño poblacional del camarón $M$. borellii y del cangrejo $T$. borellianus en una laguna conectada sugirieron posibles movimientos y mortalidad en períodos de aguas bajas. El mayor porcentaje y frecuencia de recapturas observadas en $T$. borellianus indicarían tasas de dispersión diferencial en las especies $M$. borellii y $T$. borellianus. Las tallas de cangrejos y camarones más recapturados fueron las intermedias en ambas especies. La ocurrencia de movimientos de individuos entre poblaciones, conectividades y aislamientos poblacionales, se evidenciaron durante el trabajo determinando dinámicas metapoblacionales de camarones y cangrejos en ambientes lóticos y leníticos de llanuras de inundación acorde al momento del ciclo hídrico. En conclusión, las fluctuaciones y conectividades 
hídricas en un sistema dinámico de llanura de inundación regulan cambios y movimientos de subpoblaciones de decápodos en el marco de un concepto metapoblacional. En este sentido, las fluctuaciones hídricas constituyen un macrofactor que regula otras variables ambientales y explica la riqueza, distribución y abundancia de los decápodos que viven en estos sistemas.

Freshwater decapods of the Middle Parana: relationship between population and river dynamics in a meta-population scale

Freshwater decapods populations are adjusted to the hydrodynamic of the Parana River, showing spatial distribution governed by physical, chemical and biological factors. The aim of this dissertation is to describe and analyze the metapopulation dynamics of freshwater decapods regarding water fluctuations of the Middle Parana River and its tributaries. The analysis focused on the structure of the population and its changes, in different locations and phases of the river. Decapods movements among populations were estimated as well, using as a reference different periods of the river and considering: genetic and shape variations, and differentiating temporarily connected and isolated ponds. The abundance and size of freshwater prawns and crabs changed in accordance with environmental variables, type of vegetation and micro-fluctuations of rivers. The relationships among shapes of specimens were different in several moments of the water cycle and according to meso and microgeographic scales, indicating possible movements related to the river dynamic. The existence of gene flow among populations of $M$. borellii between closest sites and high levels of heterozygosity was demonstrated. The population density of $M$. bore/lii and $P$. argentinus changed according to the connection phases of the ponds considering the interaction of the two species. The percentage and frequency of recapture observed indicated different dispersal rate between prawns and crabs in a connected pond. Water fluctuations and hydrological connectivity in a dynamic system of floodplain regulate the changes and movements of decapods subpopulations. This is a complex phenomenon that can be understood by the concept of meta-population.

\section{Efectos de la exposición perinatal a bajas dosis de Bisfenol A sobre el desarrollo y funcionalidad del tracto reproductor femenino}

\section{Lucía Vigezzi}

lucia.vigezzi@gmail.com

Director: Dr. Enrique Hugo Luque

Co-Director: Dra. Verónica Lis Bosquiazzo

Lugar de realización: Instituto de Salud y Ambiente del Litoral (UNL-CONICET). Facultad de Bioquímica y Ciencias Biológicas. Universidad Nacional del Litoral
Fecha de defensa: 11 de Marzo de 2016

En el presente trabajo de tesis estudiamos los efectos de la exposición perinatal a bajas dosis de Bisfenol A (BPA) sobre la diferenciación funcional uterina en ratas adultas en distintas edades reproductivas y en un modelo de rata ovariectomizada tra- 
tada con estrógenos. Los resultados presentados nos permitieron concluir que la exposición perinatal a BPA altera el desarrollo del útero con consecuencias adversas a largo plazo en la histología y la diferenciación funcional uterina de ratas de distintas edades reproductivas. Observamos importantes cambios en el compartimento glandular del útero, lo que sugiere que el BPA podría alterar la funcionalidad de las glándulas uterinas. También demostramos que la exposición perinatal a BPA altera la respuesta uterina al estradiol (E2) en ratas adultas de edad avanzada. Esto fue evidenciado por alteraciones en la histología y en la expresión de proteínas implicadas en la diferenciación funcional de las glándulas uterinas; y por cambios en la expresión de receptores hormonales y de moléculas asociadas a las interacciones estroma-epitelio mediadas por E2. En esta tesis se presentan evidencias experimentales de efectos adversos de la exposición perinatal a BPA sobre la diferenciación funcional del útero y en consecuencia, la salud reproductiva de la hembra. Estos resultados deberían contribuir a la toma de conciencia para promover la elaboración de normas que regulen/ eviten la exposición a químicos clasificados como perturbadores endocrinos que contaminan el medio ambiente y que afectan la salud animal y de los seres humanos.
Effects of perinatal exposure to low doses of Bisphenol $A$ on the development and function of the female reproductive tract

In the present work we investigated the long-term effects of perinatal exposure to low doses of Bisphenol A (BPA) on the uterine functional differentiation in adult rats at different reproductive stages; and in ovariectomized adult rats treated with Estrogen. The results presented here demonstrate that perinatal exposure to low doses of BPA alters the histology and uterine functional differentiation of rats from different reproductive ages. We observed significant changes in uterine glands, suggesting that BPA could alter the glandular function. We also demonstrated that perinatal exposure to BPA alters the uterine response to estradiol (E2) in aged rats. This was evidenced by alterations in the histology and the expression of proteins involved in the glandular functional differentiation; and by changes in the expression of hormonal receptors and molecules involved in stromal-epithelial interactions mediated by E2. In this thesis we presented experimental evidence showing adverse effects of perinatal exposure to BPA on the uterine functional differentiation and therefore, the female reproductive health. These results should contribute to promote the elaboration of future norms that will regulate the degree of human and wild life exposure to chemicals classified as endocrine disruptors. 


\section{Resúmenes de Tesis: Doctorado en Educación en Ciencias Experimentales}

\section{La interpretación de la evolución biológica mediante representaciones icónicas y diagramas filogenéticos}

\section{Marcela Torreblanca \\ mtorreblanca@fibertel.com.ar \\ Director: Dr. Agustín Aduríz-Bravo \\ Co-Director: Dr. Sebastián Apesteguía \\ Lugar de realización: Junín, Provincia de Buenos Aires \\ Facultad de Bioquímica y Ciencias Biológi- cas - Facultad de Humanidades y Ciencias. Universidad Nacional del Litoral. \\ Fecha de la defensa: 2 de septiembre de 2016}

La epistemología y la historia de la ciencia brindan el encuadre necesario para construir secuencias didácticas en las cuales las representaciones icónicas cumplan una función sustancial para detectar preconcepciones y obstáculos epistemológicos en el proceso de aprendizaje de las teorías evolutivas, la clasificación y taxonomía, y la historia evolutiva y filogenia de los seres vivos.

Se eligió como problema de investigación la utilización de imágenes y diagramas representativos de la relación histórica y evolutiva de los seres vivos, elementos que tienen presencia conspicua en libros de texto y propuestas educativas. Se partió de los siguientes objetivos específicos: 1. analizar las producciones sobre evolución de las especies (producciones gráficas, imágenes, esquemas y diagramas, y su justificación) de estudiantes de enseñanza secundaria básica; 2. detectar los principales obstáculos en la construcción de árboles evolutivos y cladogramas; 3.confrontar las imágenes con sus justificaciones y con el discurso escrito; 4. comparar las representaciones históricas de la evolución con los obstáculos epistemológicos presentes en los estudiantes; 5. sistematizar y buscar patrones comunes en las representaciones y sus obstáculos en estudiantes de distintos niveles educativos. Para ello se efectuó un estudio longitudinal, de carácter exploratorio, con un seguimiento de los mismos estudiantes durante 3 años, teniendo en cuenta una variedad de categorías analíticas, tales como: representación lineal o ramificada; continuidad, direccionalidad y progreso; temporalidad; complejidad; diferenciación; ancestro común; descendencia con modificación. Se analizaron la correspondencia descriptiva o explicativa, la coherencia conceptual y representativa y los distintos niveles de errores conceptuales. Los mismos fueron vistos desde modelos evolutivos actuales.

De las indagaciones realizadas y del seguimiento sistematizado de las representaciones gráficas producidas por los estudiantes se infiere que el esquema de árbol no es espontáneo. Dicha representación surge cuando es enseñada por analogía con el árbol genealógico, pero se mantienen las confusiones con el desarrollo individual, la linealidad y la progresión. La concepción lineal y progresiva de la evolución resurge en los distintos niveles educativos y está fuertemente asociada a la inclusión 
del hombre dentro de los esquemas gráficos. Es significativa la separación del ser humano de los animales, o su diferenciación como peldaño superior de la evolución. Se observó asimismo una escasa relación con conocimientos previos, y también la existencia de preconcepciones erróneas y persistentes provenientes del sentido común y del imaginario colectivo. Se registró en el análisis multivariado escasa relación entre la imagen y el discurso escrito; se vio también que el lenguaje utilizado en las consignas impacta en los resultados de las producciones. La utilización de estrategias de construcción e interpretación de imágenes como activadoras resultó ser muy fructífera; en los talleres llevados adelante con los estudiantes se evidenció su utilidad como mediadoras del aprendizaje de conceptos abstractos como descendencia y ancestro común.

Como principal derivación de esta tesis se sugiere la utilización de la iconografía, las imágenes y los diagramas como instrumentos dentro de secuencias didácticas que se encuadren histórica y epistemológicamente a fin de enseñar las representaciones de la evolución de las especies y sus diversas interpretaciones.

Interpretation of biological evolution by iconic representations and phylogenetic diagrams.

Epistemology and history of science provide the necessary to build didactic sequences in which the iconic representations fulfill a substantial function to detect preconceptions and epistemological obstacles in the learning process of evolutionary theories, classification and taxonomy, evolutionary history and phylogeny of living beings.

The use of pictures and diagrams representing the historical and evolutionary relationships of living things, elements that have conspicuous presence in textbooks and educational proposals was chosen as research problem. Compare the historical representations of evolution with the epistemological obstacles in students; systematize and look for common patterns in the representations and obstacles in students from different educational levels.

A longitudinal, exploratory study, following the same students for three years was made, taking into account a variety of analytical categories, such as linear or branched representation; continuity, direction and progress; seasonality; complexity; differentiation; common ancestor; and descent with modification.

From the investigations carried out and the systematic monitoring of graphic representations produced by students is inferred that the scheme is not a spontaneous tree. It arises when such representation is taught by analogy with the family tree, but the confusions remain with the individual development, linearity and progression.

Using construction and interpretation of images strategies as activating proved very fruitful; As main proposal of this thesis, suggested use the iconography, images and diagrams as tools in teaching sequences that fit historical and epistemological representations to teach the evolution of species and their models and interpretations. 


\section{Resúmenes de Tesis: Maestría en Didáctica de las Ciencias Experimentales}

\section{Historias escolares y prácticas profesionalizantes de los estudiantes de 4to año de biología del INTVA: un desafío permanente en la formación}

\section{Sandra Mariela Vicentin \\ mvicentin57@hotmail.com \\ Directora: Mgt. Irma Irene Lucero de Barbero Co-directora: Lic. Graciela Ríos \\ Lugar de realización: Villa Ángela, Chaco - Dpto. Mayor Jorge Luis Fontana. Instituto de Nivel Terciario Villa Ángela. \\ Fecha de defensa: 04 de mayo de 2016}

Este trabajo de investigación, exploratoria descriptiva, ha tenido como finalidad encontrar algunas relaciones entre las historias personales/escolares de los alumnos del último año del profesorado de Biología del Instituto de Nivel Terciario de Villa Ángela Chaco, en relación con el estilo de implementación de sus prácticas. Los objetivos de de dicho trabajo fueron:

Analizar la historia escolar de los estudiantes practicantes del profesorado en Biología. Identificar las representaciones que se forman a partir de sus historias escolares ligadas a la enseñanza y que se plasman en sus prácticas profesionalizantes. Determinar cuáles son las enseñanzas implícitas que subyacen de las historias escolares de los estudiantes. Caracterizar las prácticas profesionalizantes de los estudiantes en el Período de Residencia Docente. Identificar los modos cómo se entrecruzan la historia escolar de los estudiantes del profesorado y sus prácticas profesionalizantes en el período de Residencia Docente.
El análisis de la información estuvo basado en las distintas variables que intervienen en: planificaciones áulicas: objetivos, estrategias de enseñanza, recursos didácticos y actividades; de obsenaciones áulicas: objetivos, actividades y estrategias de enseñanza; de las historias escolares: estrategias de enseñanza, recursos didácticos, tipos de comunicación, comunicación del ejercicio.

La información recabada permitió dar cuenta de que hay similitud entre las formas de enseñanza que han recibido en su trayectoria escolar con la que impartieron en sus prácticas áulicas como futuros docentes.

La revisión bibliográfica, referidas al pensamiento del futuro profesor ha permitido inferir que los residentes reflejan en sus prácticas áulicas características, modos de proceder, de pensar, que fueron propios del tránsito por diferentes niveles educativos porque evidentemente han dejado en la mayoría de ellos una fuerte impronta.

Conocidas y analizadas cada una de las diez clases dadas de las Planificaciones Áulicas de los alumnos residentes, se registra que de cinco residentes, la número 1 uno de ellos no se muestra del todo definida por uno de los enfoques de enseñanza, es decir que de diez clases, cinco corresponden al enfoque constructivista y cinco al academicista, en tanto que tres ( los residentes 2, 3 , y 4, muestran en las mismas, la predominancia de rasgos del enfoque construc- 
tivista, la $5^{\circ}$ residente, en tanto, apunta un poco más al enfoque academicista o tradicional en sus clases, con un esfuerzo por incorporar aspectos o rasgos del enfoque constructivista.

Teniendo en cuenta los datos que arrojaron el análisis de las Historias Escolares de dichos residentes, se puede decir que hay similitud entre las formas en las que la residente 1 ha recibido la enseñanza con la que ella hoy imparte como futura docente, es decir no se define hacia uno u otro enfoque. La residente 2 y 3 han trabajado de manera muy similar a lo que en su época de estudiante ha recibido. Se evidencian en los docentes que han transitado por su etapa escolares rasgos que apuntan mucho a un enfoque constructivista sin dejar de utilizar en algunas clases el enfoque academicista. En tanto que el residente 4 a diferencia de lo recibido durante su escolarización (clases academicistas), ha preferido apuntar a clases de tipo constructivista. Finalmente la residente 5, a mantenido el estilo de enseñanza recibida en su época escolar, la de tipo tradicional, la que ella hoy evidencia en sus clases, con un débil intento de realizar modificaciones, incorporando en algunas de ellas, aspectos del enfoque constructivista.

De cinco residentes, solo uno de ellos ha cambiado su visión respecto del modelo de enseñanza recibida, los otros cuatro han mantenido, en el momento de dar sus clases, la forma de enseñanza que han recibido durante su trayectoria escolar. 


\section{Resúmenes de Tesis: Maestría en Salud Ambiental}

\section{Evaluación del daño genético producido por exposición ambiental a plaguicidas en mujeres de edad fértil de la Provincia de Santa Fe}

\section{Prof. Lic. Gabriela Martino Durussel \\ martinogaby@yahoo.com.ar \\ Directora: Dra. María Fernanda Simoniello \\ Lugar de realización: Cátedra de Toxico- logía, Farmacología y Bioquímica Legal. Facultad de Bioquímica y Ciencias Biológi- cas. Universidad Nacional del Litoral \\ Fecha de defensa: 8 de marzo de 2016}

En las áreas rurales, las mujeres pueden estar expuestas a plaguicidas tanto ocupacional como ambientalmente. La información vinculada con la exposición a pesticidas y la salud de las mujeres es escasa y frecuentemente no publicada en la literatura científica internacional. Muchos de los efectos de los plaguicidas en la salud humana podrían ser los mismos en hombres y en mujeres pero las diferencias biológicas vinculadas con el sexo demuestran importantes variaciones en la susceptibilidad causada por la acción tóxica de estas sustancias químicas. Con el objetivo de evaluar la acción de los plaguicidas en mujeres en edad fértil, se seleccionaron como biomarcadores de exposición, las enzimas acetil y butirilcolinesterasa (AChE y BChE) y de genotoxicidad, el ensayo cometa (EC) en leucocitos de sangre periférica y su modificación para determinar pirimidinas oxidadas utilizando la enzima de reparación específica Endonucleasa III (Sitios Endo), junto con la frecuencia de micronúcleos en mucosa bucal (MNMB). Se incluyeron 46 mujeres provenientes de áreas rurales altamente pulverizadas con plaguicidas y los resultados se contrastaron con 101 controles que provenían de localidades urbanas y que además no utilizaban frecuentemente plaguicidas en su hogar. Se observaron diferencias estadísticamente significativas para AChE $(p=0,001)$ pero no para BChE $(p=0,179)$. Además se observó un incremento significativo en el daño al ADN y en el daño oxidativo en las pirimidinas en mujeres expuestas respecto de las controles ( $p$ $=0,01$ y $p<0,001$ respectivamente) pero no se obtuvieron diferencias en la frecuencia de MNMB $(p=0,85)$. Se determinó que el daño en el ADN, en mujeres expuestas, está influenciado por el consumo de alcohol y por realizar trabajos rurales ( $p<0,05)$. La frecuencia de MNMB también estuvo influida por realizar tareas rurales $(p=0,02)$ Estos resultados permiten seleccionar a AChE y Sitios Endo como biomarcadores adecuados para poblaciones expuestas ambientalmente a plaguicidas. Como consecuencia, se resalta la importancia del desarrollo de estrategias para intervenir y atenuar la exposición a plaguicidas, que podría reducir potencialmente la incidencia de sus efectos sobre la salud. 
Assessment of genetic damage due to environmental exposure to pesticides in reproductive age women of Santa Fe province

In the rural areas, women may be occupationally- or environmentally exposed to pesticides. Pesticide exposure and women's health information is scarce and frequently not published in the international scientific literature. Many of the effects of pesticides in human health could be the same for males and females, but sex-related biological differences strongly support a distinct susceptibility to the toxic action of these chemicals. In order to evaluate the action of pesticides on reproductive-age women, we selected acetyl and butyrylcholinesterase enzymes (BChE and AChE) as biomarkers of exposure, while the comet assay (EC) in peripheral blood leukocytes, its modification to determine oxidized pyrimidines using specific repair enzyme endonuclease III (Endo sites)and the frequency of micronuclei in buccal cells (BCMN), were used as biomarkers of genotoxicity. A total of 46 women from rural areas highly sprayed with pesticides were studied and their results were compared with 101 controls from urban localities without frequent use of pesticides in their homes. A statistically significant difference was observed between exposed and controls in AChE $(p=0.001)$ but not in BChE ( $p=0.179)$. Furthermore a significant increase in DNA damage and oxidative damage in pyrimidines was found in exposed women respect to controls ( $p$ $=0.01$ and $p<0.001$, respectively) but no differences were obtained in the frequency of BCMN ( $p=0.85)$. It was determined that DNA damage in exposed women is influenced by alcohol and by performing rural work $(p<0.05)$. BCMN frequency was also affected by performing rural activities $(p=$ 0.02). These results allow us to select $A C h E$ and Endo III sites as suitable biomarkers for the study of populations environmentally exposed to pesticides. It has to be high light the importance of developing strategies to intervene and mitigate exposure to pesticides, which could potentially reduce its incidence on human health.

\section{Procesos químicos en los suelos. Su impacto en la salud ambiental. Dosis de fertilizantes, nutrientes biodisponibles en suelos agrícolas de la provincia de Santa Fe}

\section{Azucena Margarita Mondino}

amondino@fbcb.unl.edu.ar

Director: Dr. Héctor Santiago Odetti

Lugar de realización: Laboratorio de Investigación, Departamento de Química General e Inorgánica. Facultad de Bioquímica y Ciencias Biológicas. Universidad Nacional del Litoral

Fecha de defensa: 14 de octubre de 2016
Es un motivo de preocupación actual, intensificar la producción agrícola a los efectos de abastecer una creciente demanda de alimentos de la población mundial, que se calcula estará en 9000 millones de personas para el año 2050. Esta intensificación no es viable incrementando las tierras cultivables avanzando sobre bosques y zonas de nuestro planeta que sirven para mantener el equilibrio ecológico ambiental. 
La intensificación agrícola sustentable puede lograrse aplicando mejores prácticas de manejo en materia de nutrición vegetal, obteniendo más rendimiento por unidad de superficie y mayor número de cultivos por hectárea por año.

El fósforo $(P)$, es luego del nitrógeno $(\mathrm{N})$, el nutriente que con mayor frecuencia afecta la producción de las plantas. Aun cuando los requerimientos de $P$ de los cultivos no son elevados, las cantidades directamente disponibles para los cultivos suelen ser reducidas. Un considerable aumento del P-disponible se logra con la adición de nutrientes fosfatados.

Si bien el uso de fertilizantes en forma adecuada es necesario para recuperar el estado nutricional óptimo del suelo, el uso abusivo sin tener en cuenta los movimientos químicos internos que en él se originan, puede resultar en una degradación de la calidad y rendimiento futuro de las tierras.

Este trabajo presenta un modelo de fertilización que puede calcularse para cada suelo en particular, teniendo en cuenta las características físico-químicas propias del mismo. Debe tenerse en cuenta que las técnicas extractivas usadas habitualmente para determinar el contenido de fósforo de los suelos evalúan el fósforo total y no el disponible para las plantas.

El fósforo biodisponible se encuentra en equilibrio con el fósforo adsorbido y es afectado por numerosos factores físicos y químicos, del suelo y de la planta.

Inicialmente se realiza un análisis de suelo para conocer las características físicas y químicas del mismo.

Luego se determina la relación entre el contenido de fósforo total del suelo y el fósforo biodisponible, no hallando vinculación entre los mismos.
Finalmente, el trabajo propone el uso de herramientas sencillas, como son la realización de las isotermas de adsorción para calcular la dosis óptima de fertilizante fosforado que debe agregarse al suelo para lograr niveles de fósforo adecuado a los cultivos.

Las isotermas experimentales pueden ajustarse con modelos estadísticos que permiten obtener parámetros matemáticos que tienen relación con los procesos cinéticos que ocurren en los suelos y que nos permiten calcular la dosis de fertilizante en forma más precisa y específica, para cada suelo en cuestión.

Los resultados nos muestran buena correlación entre las dosis calculadas con el modelo y los niveles de fósforo biodisponibles alcanzados en la solución del suelo luego de la fertilización. La dosis de fertilizante calculada con el modelo, es menor que la propuesta por otros sistemas de cálculo para el suelo en cuestión, permitiendo disminuir los costos de producción y proteger al medio ambiente, específicamente al suelo que es un recurso no renovable, de importante protagonismo futuro para alimentar a la población mundial.

\section{Chemical Processes in Soils. Its impact} on Environmental Health. Dosage of BioBioavailable Fertilizers in Soils of the Province of Santa Fe

Is a reason of current concern, intensifying agricultural production to supply a growing demand of food of the world population, which is estimated to be 9000 million people by 2050. This intensification is not viable to increase arable land advancing forests and areas of our planet that serve to maintain the environmental ecological balance.

Sustainable agricultural intensification can be achieved by applying best man- 
agement practices in plant nutrition, getting more yield per unit area and greater number of crops per hectare per year.

Phosphorus $(P)$ is after nitrogen $(N)$, the nutrient that most often affects the production of plants. Even when requirements of $P$ of crops are not high, the quantities directly available for crops are generally reduced. A significant increase of P-available can be achieved with the addition of phosphate nutrients.

While properly use of fertilizers is necessary to recover the optimal nutritional state of the soil, the misuse regardless of the internal chemical movements that therein originate, can result in a degradation of the quality and future performance lands.

This paper presents a model of fertilization that can be calculated for each particular soil, considering the physical-chemical characteristic of it. It should be noted that extractive techniques commonly used to determine the phosphorus content of the soil total phosphorus and not plant-available. The bioavailable phosphorus is in equilibrium with the adsorbed phosphorus and is affected by many physical and chemical factors, of soil and plant.

Initially, a soil analysis is realised to meet the physical and chemical characteristics.
The relationship between the content of total phosphorus soil and bioavailable phosphorus is then determined, finding no link between them.

Finally, the paper proposes the use of simple tools, such as the realization of the adsorption isotherms to calculate the optimal dose of phosphorus fertilizer to be added to soil to achieve adequate levels of phosphorus to crops.

The experimental isotherms can be adjusted with statistical models to obtain mathematical parameters that are related to the kinetic processes occurring in soils and that allow us to calculate the dose of fertilizer more precisely and specifically, for each floor in question.

The results show good correlation between the calculated dose pattern and levels of bioavailable phosphorus achieved in the soil solution after fertilization. The fertilizer rate calculated by the model is lower than that proposed by other computing systems for the land in question, enabling decrease production costs and protecting the environment, specifically the soil, which is a nonrenewable resource, an important role to feed the future world population. 


\section{Resúmenes de Trabajos Finales Integradores: Especialización en Vinculación y Gestión Tecnológica}

\section{Sistema de Vigilancia Tecnológica a cargo de una organización de Desarrollo Territorial. El caso del Parque Industrial de Crespo, provincia de Entre Ríos}

\section{Ernesto Jerónimo Kemmerer \\ ejkemm@fibertel.com.ar \\ Director: Ing. Marcelo Grabois}

Co-Director: Dr. José David Barberá Tomás Lugar de realización: Facultad de Bioquímica y Ciencias Biológicas. Universidad Nacional del Litoral.

Fecha de defensa: 07 de noviembre de 2016.

El presente trabajo plantea tendencias mundiales sobre el reto de la competitividad económica y la globalización de los mercados, y su influencia en las organizaciones locales territoriales, haciendo foco en el Parque Industrial de Crespo (en adelante PIC) y sus zonas de influencia. Se evalúan la dinámica de crecimiento de los avances tecnológicos, sus impactos previsibles y la necesidad de achicar la brecha tecnológica, para aprovechar las oportunidades y neutralizar las amenazas que tales tendencias traen consigo.

A partir de este contexto, y luego de analizar casos nacionales e internacionales semejantes, se propone la creación de una Unidad de Vigilancia Tecnológica (en adelante UVT) que bregue por reducir las brechas, evidenciando tendencias actuales y futuras, identificando tecnologías emergentes de modo temprano, facilitando con ello, la toma de decisiones de los líderes de las organizaciones del PIC. Se plantea la estructura de tal Unidad, su configuración funcional, los resultados esperables y los recursos necesarios tanto humanos como materiales y de software para su implementación. Además de estimar el presupuesto necesario para su implementación se presenta un análisis FODA (fortalezas, oportunidades, debilidades y amenazas) incluyendo variables controlables y no controlables que permiten evaluar el impacto sobre el PIC.

System of Technological Vigilance in charge of an organization of Territorial Development. The case of the Industrial Park of Crespo, in the state of Entre Ríos.

In this work we present global trends regarding the challenges on economic competitiveness and markets globalization, and their influence on local land organizations, focusing on the Industrial Park of Crespo (PIC) and its influence areas. We evaluate the growing dynamics of technological breakthroughs, their foreseeable impacts and the need to reduce the technological gap, in order to take advantage of the opportunities and neutralize the threats that such trends bring along.

Considering this context, and after having analyzed similar national as well as international cases, we propose the creation of a Technological Vigilance Unit (UVT), aimed to reduce the gaps, evidencing current and future trends, early identifying emerging 
technologies, and facilitating the decision making process carried out by the leaders of the organizations in the PIC. We present the structure of the Unit, the configuration of its functions, the expected results, and the human, material and software resources needed for its implementation. We estima- ted the budget required for the implementation, as well as a FODA analysis (strengths, opportunities, weaknesses and threats), including the controllable and uncontrollable variables, which allow us to evaluate the impact over the PIC. 